\title{
O PRIMADO DA SOCIEDADE E AS FALHAS DO DIREITO E DESENVOLVIMENTO ${ }^{1}$
}

\author{
Brian Z. Tamanaha \\ THE PRIMARY OF SOCIETY AND THE FAILURES \\ OF LAW AND DEVELOPMENT \\ TRAdução Tatiane Honório Lima REVISÃo tÉcnICA José Rodrigo Rodriguez
}

\section{RESUMO}

O TEXTO ANALISA OS FRUTOS DOS ESFORCOS DE DIREITO E DESENVOLVIMENTO PARA MOSTRAR COMO SEUS RESULTADOS SÄO DISCUTÍVEIS. TAMBEÉM EXAMINA O CONJUNTO DE CONHECIMENTOS ACUMULAdOS ACERCA DAQUILO QUE FUNCIONA EM DIREITO E DESENVOLVIMENTO PARA MOSTRAR COMO ELE É INCONCLUSIVO. PARA FAZER ISSO, EXTRAI AS IMPLICAÇ̃EES DO PRIMADO DA SOCIEDADE PARA - DIREITO E DESENVOLVIMENTO, ABORDAGEM QUE AFIRMA ESTAR O DIREITO INTERCONECTADO COM TUDO NA SOCIEDADE, DE TAL MODO QUE TUDO IMPORTA. ESSA É A PERCEPCÃO FUNDAMENTAL DA INVESTIGAÇÃO CONDUZIDA PELA ESCOLA DO LAW \& SOCIETY, MORADA ORIGINAL DO TRABALHO QUE, AGORA, É CONDUZIDO SOB O RótULO dE DIREITO E DESENVOLVIMENTO.

PALAVRAS-CHAVE

Direito; Desenvolvimento; LaW \& Society; América Latina.

\section{ABSTRACT}

THE PAPER EXAMINES THE FRUITS OF THE EFFORTS OF LAW \& DEVELOPMENT TO SHOW HOW THEIR RESULTS ARE DEBATABLE. IT ALSO EXAMINES THE ACCUMULATED BODY OF KNOWLEDGE ABOUT WHAT WORKS IN LAW \& DEVELOPMENT TO SHOW HOW IT IS INCONCLUSIVE. TO DO THIS, IT DRAWS THE IMPLICATIONS OF THE PRIMACY OF THE SOCIETY FOR LAW \& DEVELOPMENT, AN APPROACH THAT ASSERTS THAT LAW IS INTERCONNECTED WITH EVERYTHING ELSE IN SOCIETY, SO EVERYTHING MATTERS. THIS IS THE FUNDAMENTAL INSIGHT OF THE INVESTIGATION CONDUCTED BY LAW \& SOCIETY, ORIGINAL HOME OF THE WORK THAT NOW IS CONDUCTED UNDER THE LABEL OF LAW \& DEVELOPMENT.

KEYWORDS

LAW; DeVELOPMENT; LAW \& SOCIETY; LATIN AMERICA.

\section{INTRODUÇÃO}

Os esforços feitos em Direito e Desenvolvimento já se estendem por mais de meio século. Suas designações mudaram ao longo do tempo: nas décadas de 1950, 1960 e 1970, a disciplina foi denominada Movimento Direito e Desenvolvimento; ${ }^{2}$ na década de 1980, não possuía uma designação específica; na década de 1990 e durante a virada do século, de "programas de boa governança", transformou-se em "Império do direito e Desenvolvimento". Nas últimas décadas, um modesto apoio financeiro foi fornecido por algumas agências e fundações de fomento à pesquisa; na década de 1990, o fluxo de financiamento aumentou repentina e consideravel- 
mente, por meio do apoio financeiro oriundo de várias organizações, apoio esse que somou, de forma cumulativa, bilhões de dólares. ${ }^{3}$

Esse esforço do Direito e Desenvolvimento envolveu uma quantidade incalculável de projetos em todo o mundo, concentrando-se na melhoria da educação jurídica; implementando a reforma jurídica, a constituição ou a elaboração de códigos; transplantando leis e instituições, assim como a formação na execução da lei; combatendo a corrupção; educando leigos a respeito do Direito; fornecendo aos pobres acesso à legislação; e prestando assistência material para a criação de instituições jurídicas (incluindo elementos básicos, como suprimentos de escritório, computadores e material jurídico). Há inúmeros relatórios de projeto, estudos locais ou de Estado, nacionais ou transnacionais, bem como estudos comparativos, que abrangem desde avaliações de projetos até estudos antropológicos, relatos históricos, estudos estatísticos e amplas visões gerais.

O trabalho elaborado pelo Direito e Desenvolvimento é financiado ou realizado pelas principais instituições nacionais e internacionais, públicas e privadas, incluindo, de modo proeminente, o Banco Mundial, a Fundação Ford, a Fundação Carnegie para a Paz Internacional, a Ordem dos Advogados dos Estados Unidos, o Programa das Nações Unidas para o Desenvolvimento (PNUD), a Agência Norte-Americana para o Desenvolvimento Internacional (USAID), o Banco Interamericano de Desenvolvimento (BID), o Banco Europeu para Reconstrução e Desenvolvimento, o Departamento Britânico para o Desenvolvimento Internacional (DFID), o Banco Asiático de Desenvolvimento, a Agência de Cooperação Internacional do Japão (JICA) e muitas outras.

Quais são os frutos desse esforço dispendioso e prolongado? Há dois aspectos distintos a serem levados em conta nesta questão. O primeiro considera em que medida o Direito e Desenvolvimento foi consolidado no local. O segundo aspecto concentra-se no conjunto de conhecimentos acumulados acerca daquilo que funciona em Direito e Desenvolvimento.

Uma avaliação honesta compele a uma conclusão infeliz sobre ambos. Tendo em vista a maioria dos relatos, foram escassas as melhorias reais no direito constatadas a partir de tais esforços. Thomas Carothers (2006), diretor do projeto de Império do direito (Rule of Law) para a Fundação Carnegie, oferece a seguinte avaliação:

Os efeitos desse crescente apoio ao Império do direito são, em geral, positivos, embora comumente modestos. Depois de mais de dez anos e centenas de milhões de dólares de subsídio, muitos sistemas jurídicos na América Latina ainda funcionam mal. A Rússia é, provavelmente, a única e maior beneficiária de tal subsídio, mas não está sequer caminhando visivelmente na direção correta. Os numerosos programas de Império do direito realizados no Camboja, após as eleições de 1993, malograram 
em criar valores ou estruturas suficientemente fortes para evitar o golpe de Estado ocorrido no ano passado. Os mantenedores dos subsídios ajudaram a reescrever as leis em todo o mundo, mas descobriram que a mera promulgação de leis pouco alcança sem um investimento considerável na alteração das condições de implementação e execução [...] Os esforços para fortalecer as instituições jurídicas básicas revelaram-se lentos e difíceis. A formação de juízes, as consultorias técnicas e outras transferências de conhecimento especializado fazem sentido no papel, mas apresentam, com frequência, somente um pequeno impacto. (p. 11-2)

Infelizmente, os problemas são piores do que essa passagem revela, porque ela omite a menção ao fracasso mais desalentador. ${ }^{4}$ Durante o mesmo período, mais de cem milhões de dólares foram gastos em Direito e Desenvolvimento na África, com resultados que têm sido caracterizados como "bastante deprimentes" (PIRON, 2006, p. 289). Em toda a literatura sobre Direito e Desenvolvimento, há "uma forte corrente de decepção” (GARTH, 2002, p. 383-4).

Carothers (2006) também oferece uma avaliação sóbria a respeito do que se tem aprendido sobre Direito e Desenvolvimento a partir de tal esforço. Um participante de longa data confidenciou-lhe que "sabemos como fazer muitas coisas, mas, no fundo, nós não sabemos exatamente o que estamos fazendo” (p. 15). O trabalho nesse campo opera:

[...] a partir de uma incômoda e fraca base de conhecimento em cada nível - relacionada à lógica central do trabalho, à questão referente ao local em que a essência do Império do direito realmente reside nas diferentes sociedades, a como ocorre a mudança no Império do direito e quais são os efeitos reais das mudanças que são produzidas. As lições aprendidas até agora, na maior parte dos casos, não impressiona e, muitas vezes, parecem que não foram realmente aprendidas. (p. 27)

A avaliação desencorajadora de Carothers sobre os frutos dos esforços empreendidos pelo Direito e Desenvolvimento parece ser amplamente partilhada pelos envolvidos em tal trabalho. Uma revisão de três notáveis livros recentes sobre Direito e Desenvolvimento observou que:

Embora as contribuições feitas a estes volumes reflitam décadas de experiência prática e reflexões acadêmicas sobre as reformas jurídicas ocorridas nos países em desenvolvimento, tais contribuições são, no fim das contas, notadamente inconclusivas. Nenhum dos autores representados nestes volumes parece fortemente otimista sobre a hipótese de as reformas 
jurídicas serem capazes de promover o desenvolvimento (ao menos no início da trajetória de desenvolvimento). (DAVIS; TREBILCOCK, 2008, p. 895)

O máximo que um otimista pode dizer é que é prematuro tirar conclusões excessivamente pessimistas. "Levará muitos anos, ou até mesmo décadas, antes que se torne evidente se o impacto prolongado de fato ocorre e em que medida" (GOLUB, 2008, p. 125).

Ao menos uma lição clara se destaca em meio à névoa: a sociedade é o centro de gravidade absoluto do Direito e Desenvolvimento. O termo "sociedade" é aqui usado em um sentido amplo - abrangendo a totalidade da história, a cultura, os recursos humanos e materiais, as composições religiosas e étnicas, a demografia, o conhecimento, as condições econômicas e a política. Nenhum aspecto do Direito e Desenvolvimento opera ou pode ser entendido isoladamente em relação a esses fatores circundantes. As qualidades, o caráter, os efeitos e as consequências do direito são completa e inescapavelmente influenciados pela sociedade circundante. Visto que cada contexto jurídico presente em cada sociedade envolve uma reunião única de forças e fatores, pode não haver nenhuma fórmula padrão para a regulação; uma lei que seja boa em um lugar pode apresentar efeitos ruins ou ser disfuncional em outro; consequências inesperadas podem vir a ocorrer.

Intelectuais e profissionais do Direito e Desenvolvimento reconhecem a seguinte verdade fundamental: "o contexto importa", "as condições locais são cruciais", "as circunstâncias locais configuram a maneira como as coisas funcionam" - variações dessa percepção têm se repetido tantas vezes que se pode considerá-la quase como um clichê. ${ }^{6}$ O que tolhe os projetos de Direito e Desenvolvimento repetidamente é a "extrema inter-relação de tudo com todo o resto numa sociedade" (KENNEDY, 2006, p. 153). ${ }^{7}$ Por razões de conveniência, chamarei tal estado de "concatenação do princípio jurídico". 8

O reconhecimento de que o Direito está interconectado com tudo na sociedade pode facilmente conduzir a uma de duas tentações antagônicas. Visto que é impossível saber ou considerar tudo, um caminho é desistir, em desespero, frente à enormidade da tarefa. O outro caminho é dar de ombros e abrir caminho assim mesmo, usando modelos gerais no transplante de códigos jurídicos, no suporte aos tribunais e na formação de advogados, esperando o melhor. Profissionais do Direito e Desenvolvimento têm feito, em grande medida, o que o segundo caminho preconiza. Avançar é, sem dúvida, melhor do que desistir e não enfrentar o problema.

O objetivo do presente ensaio é extrair as implicações do primado da sociedade para o Direito e Desenvolvimento. Colocar as questões na perspectiva adequada ajuda, a princípio, a reconhecer que a percepção central anteriormente identificada - por exemplo, a de que o direito está interconectado com tudo na sociedade, de tal modo que tudo importa - aplica-se plenamente a todos os sistemas jurídicos. 
Essa é a percepção fundamental da investigação conduzida pela escola do Law \& Society, morada original do trabalho que, agora, é conduzido sob o rótulo de Direito e Desenvolvimento. ${ }^{9}$

\section{Direito e Desenvolvimento não é UM CAMPo}

Muitos daqueles que escrevem sobre Direito e Desenvolvimento parecem considerálo um "campo". "Com um conjunto reconhecível de atividades que compõem o domínio de assistência do Império do direito” escreve Carothers (2006, p. 28), “a assistência do Império do direito tomou o caráter de um campo de auxílio coerente”. Começarei argumentando que, pelo contrário, é enganoso conceber o Direito e Desenvolvimento dessa maneira.

O Direito e Desenvolvimento é uma categoria mal construída, a qual carece de coerência interna. Cada ordenamento jurídico, em todo lugar, passa pelo desenvolvimento (ou regressão), de tal modo que não há nada de especial quanto a isso; entretanto, os múltiplos países que têm sido alvo de projetos de Direito e Desenvolvimento diferem radicalmente uns dos outros. Portanto, não existe nenhuma base unificadora exclusiva sobre a qual se possa formar um "campo". Em vez disso, o trabalho do Direito e Desenvolvimento é mais bem visto como uma aglomeração de projetos perpetuados por atores motivados e que contam com o apoio de financiamentos. Isso não significa uma caracterização cínica, mas uma descrição exata, que coloca as atividades do Direito e Desenvolvimento num plano mais adequado. Uma rápida apreciação de alguns países ajudará a reforçar esse ponto.

A Rússia é um país industrializado conduzido por um sistema de governo semiautoritário e com um exército formidável, lutando para fazer a transição de décadas de comunismo para o capitalismo global. A economia russa entrou em colapso após a transição e cresceu de forma hesitante desde então. ${ }^{10} \mathrm{O}$ país desfruta de amplos recursos naturais, incluindo reservas significativas de gás natural; possui uma população instruída, um significativo corpo de advogados, um pequeno grupo de ultrarricos, uma notável presença do crime organizado e uma força policial infestada pela corrupção. Além disso, a Rússia abrange uma enorme extensão territorial, indo da Europa Oriental até o Pacífico, abarcando grandes subpopulações de diferentes grupos étnicos e de religiões, culturas e línguas diversas.

O Paquistão é uma populosa nação islâmica na região montanhosa da Ásia, com fervilhantes cidades modernas, agitadas pela atividade econômica, e vastos trechos rurais em que as pessoas vivem em condições semelhantes àquelas de séculos atrás. O exército tem autonomia em relação ao Poder Executivo do governo e possui forte influência sobre os assuntos internos. Desde que o Paquistão conquistou a independência em relação ao governo britânico, em 1947, separando-se, em seguida, da Índia como uma nação islâmica, em 1956, há oscilação entre eleições democráticas e 
golpes militares. Nos últimos anos, a produção paquistanesa voltada para exportação e setores de serviço tem crescido num ritmo invejável, superior àquele da maioria dos países capitalistas mais avançados, embora essa produção esteja sujeita a intermitentes atrasos. A carreira jurídica e os tribunais estão bem estabelecidos nas cidades, mas tribunais do Estado nas zonas rurais são insignificantes, corruptos e padecem de longos atrasos; e há poucos advogados para atender à população rural. Ademais, os talibãs controlam certas regiões do país situadas fora das cidades, nas quais eles impõem a marca severa da charia. ${ }^{11}$

Muitas nações na África Subsaariana possuem Estados fracos (ou falidos), pouco desenvolvimento ou produção industrial, instalação elétrica não confiável, uma infraestrutura inadequada de comunicação, transporte e saneamento, sistemas educacionais ruins e um serviço de saúde precário (incluindo uma devastadora epidemia de AIDS). Parte substancial da população vive em setores agrícolas empobrecidos. Os cargos governamentais são a principal fonte de emprego. Muitos países africanos possuem, relativamente, poucos advogados e juízes formados (por exemplo, com 7,5 milhões de habitantes, Ruanda é atendida por cerca de 50 advogados, 20 procuradores e 50 juízes recém-recrutados; o Maláui possui 300 advogados para 9 milhões de pessoas) (PIRON, 2006). As nações africanas, muitas delas com populações relativamente pequenas (menos de 20 milhões de habitantes), herdaram um legado colonial que combina uma mistura preocupante de tribos africanas ou grupos étnicos rivais com descendentes de colonos brancos e outros imigrantes. A tensão entre os grupos ocasionalmente irrompe em violência, como ocorreu, em grande escala, em Ruanda, no meado da década de 1990, entre os hutus e tutsis. Os países africanos têm sido assolados por guerras civis e golpes recorrentes, que refletem as rivalidades étnicas ou tribais subjacentes. Vários países possuem ricas reservas de recursos naturais, controladas por chefes de governo ou por empresas oligárquicas que possuem laços estreitos com o governo. O governo autocrático é comum, com governantes dedicados a manter o poder, transferir a riqueza e recompensar seus partidários.

Rússia, Paquistão e Ruanda possuem certos aspectos em comum - se observados sob um ponto de vista que torne todos os detalhes invisíveis. Mas o que Rússia, Paquistão e Ruanda têm em comum com Argentina, Bolívia, Chile, China, Costa Rica, Equador, Egito, El Salvador, Honduras, Maláui, Marrocos, Paraguai, Filipinas e Romênia? Todos esses países são abordados em algum detalhe no livro de Carothers (2006) sobre o Império do direito e Desenvolvimento. Também são mencionado no livro Bangladesh, Bulgária, Camboja, Indonésia, Quênia, Peru, Romênia, África do Sul, Venezuela e Vietname. A lista continua. Esses diversos países diferem entre si em praticamente todos os aspectos: população, recursos naturais, história, cultura, mistura de religiões e grupos étnicos, sistema político, grau de industrialização, produção agrícola, posição competitiva no comércio global, grau de urbanização, renda per capita, proporção de classe média, quantidade de advogados, remuneração 
e status dos juízes - para citar algumas características. O único traço evidente que esses diversos países compartilham é o de que estão no escopo final dos projetos ou das investigações do Direito e Desenvolvimento.

Nenhum país capitalista avançado - América anglo-saxônica, Europa Ocidental, Japão e, mais recentemente, Coreia e Taiwan - está na lista do Direito e Desenvolvimento. A elegibilidade para o Direito e Desenvolvimento é definida em termos negativos: qualquer país que não tenha sido admitido no clube do capitalismo avançado. Um critério inteiramente negativo para inclusão priva o "Direito e Desenvolvimento" de qualidades compartilhadas sobre as quais é possível construir percepções. A capacidade de interconexão do direito na sociedade acentua esse problema e torna perigoso fazer inferências ou aplicar experiências de uma situação a outra. O sucesso ou o fracasso de um projeto de reforma jurídica na Rússia terá pouco impacto sobre o mesmo projeto em Ruanda ou nas isoladas colinas e vales do Paquistão.

Ademais, a falta de coerência interna é agravada pela profunda contestação acerca da orientação do "Direito e Desenvolvimento". As três principais maneiras de construir esta frase, retomada em ordem a seguir, são desenvolvimento jurídico, desenvolvimento econômico e jurídico e amplo Direito e Desenvolvimento.

\section{Desenvolvimento JURídico}

O "desenvolvimento jurídico" se concentra na criação, na expansão, na consolidação ou na melhoria da eficiência de instituições que fazem, aplicam e reforçam o direito. No contexto de desenvolvimento, o "Império do direito" frequentemente focaliza a reforma dos tribunais (treinamento, subsídio material, pesquisa). ${ }^{12}$ Isso porque as instituições jurídicas ocupam posição central nos sistemas jurídicos e se dedicam exclusivamente a eles, e, ainda, porque os tribunais são fracos se comparados a outras instituiçõos governamentais. ${ }^{13}$

A questão fundamental é que a reforma não funcionará se simplesmente focar os tribunais ou mesmo a lei. A formação de juízes por si só pouco satisfaz. Faz-se necessário um grupo de profissionais jurídicos, para lidar com casos criminais e cíveis, bem como auxiliar a desenvolver práticas jurídicas estáveis e conhecimento jurídico partilhado. O material jurídico deve estar disponível. São necessários oficiais de justiça e escreventes, para executar e registrar as medidas judiciais. Os vencimentos judiciais devem ser estabelecidos num patamar suficiente para atrair indivíduos qualificados e para diminuir a tentação de complementação dos ganhos com outras fontes de renda que comprometam sua função jurídica. Os juízes têm de resistir à influência advinda dos preconceitos, das lealdades de classe ou grupo, dos chamados da amizade ou das redes de relações expandidas, ou de outros fatores inapropriados; eles precisam ter segurança profissional e individual. Não devem estar sujeitos a intimidações ou ameaças vindas de chefes de guerra, de narcotráfico, do crime organizado, 
ou de outros elementos perigosos presentes na sociedade. A comunidade deve obedecer, em geral, às decisões judiciais, as quais têm de ser apoiadas por sanções efetivas quando não houver o seu cumprimento. Os dirigentes políticos, os líderes militares, a elite econômica, a polícia e os funcionários públicos devem, em geral, respeitar as decisões judiciais, incluindo aquelas que vão contra seus interesses ou que frustram seus objetivos.

Esta lista básica de condições necessárias ao funcionamento do sistema judicial do Estado expõe a dimensão assustadora da tarefa. Cada aspecto depende de outros fatores que alcançam âmbitos para além do próprio direito. Não há uma única peça que funcione isoladamente. O modelo idealizado de funcionamento das instituições jurídicas (que nunca é perfeitamente alcançado, em nenhum sistema), que os reformadores tentam reconstruir, funciona corretamente, pois uma série de condições secundárias favoráveis também está no lugar certo, envolvendo uma confluência de fatores sociais, econômicos, culturais e políticos.

Colocando em termos mais básicos, o Império do direito existe quando funcionários governamentais e cidadãos estão, em geral, vinculados à lei e a cumprem. ${ }^{14}$ Um componente essencial do Império do direito é a existência de uma ética prevalecente de cumprimento voluntário das decisões judiciais. Isso depende da presença de uma atitude cultural generalizada de respeito à lei e a juízes, a qual não pode ser assegurada apenas pela ameaça de coerção. As atitudes culturais, no entanto, são extremamente difíceis de serem configuradas ou alteradas deliberadamente.

A dificuldade em incentivar e defender uma atitude cultural pervasiva de respeito à lei e aos juízes é maior quando estes são vistos com desconfiança ou evitados de forma ampla - considerados corruptos, identificados com a elite, vistos como marionetes do regime, ou, ainda, como supostos favorecedores de um grupo determinado à custa de outros; ou quando a população é alienada da lei, por esta ser manchada por um passado ou presente colonial ou autoritário; ou porque a lei é escrita numa linguagem que a população não compreende ou que foi transplantada de outro local e, por isso, é considerada obscura ou estranha; ou quando os juízes são considerados inadequados; ou, ainda, quando o sistema judicial é proibitivamente caro, padece de longos atrasos e outras ineficiências etc. Se esses problemas existem, separadamente ou combinados, os tribunais do Estado podem ser ineficazes, marginalizados ou mesmo desprezados pelos cidadãos.

Um proeminente cientista político que estudou a região durante décadas observou que, na maior parte da América Latina, "o Poder Judiciário é demasiado distante, complicado, caro e lento para que os pobres sequer tentem ter acesso a ele. E se conseguem obter acesso jurídico, as provas disponíveis muitas vezes apontam para a discriminação grave e sistemática" (O’DONNELL, 2004, p. 40-1). Da mesma forma, juízes em alguns países da Ásia Oriental são vistos como tendenciosos (com maior predileção pelo Estado) ou corruptos; na Indonésia, por exemplo, onde levantamentos mostram 
baixos níveis de respeito pelos tribunais, ${ }^{15}$ as pessoas levam a maioria dos seus litígios a mecanismos comunitários informais ou a líderes religiosos. ${ }^{16}$ Outrossim, acredita-se que mais “de $80 \%$ a $90 \%$ dos litígios diários que ocorrem na África são resolvidos por meio de sistemas não estatais, como as autoridades tradicionais" (PIRON, 2006, p. 291). O Departamento Britânico para o Desenvolvimento Internacional estima que "em muitos países em desenvolvimento, sistemas jurídicos tradicionais ou habituais são responsáveis por 80\% dos casos totais” (GOLUB, 2006, p. 118), o que é, provavelmente, uma estimativa atenuada. ${ }^{17}$

Um estudo acerca dos esforços malsucedidos de reforma jurídica na América Latina concluiu que, "Em resumo, só se pode esperar um bom julgamento quando todos os elementos do ordenamento jurídico são reformados, quando a sociedade civil apoia ativamente a reforma, e quando a cultura política deposita grande valor num judiciário reformado" (DODSON, 2008, p. 202). Instituições jurídicas exigem estabilidade social, amplos recursos humanos, recursos econômicos suficientes, atitudes culturais favoráveis em relação à lei e estabilidade política. Na ausência dessas condições, será difícil que as reformas jurídicas tenham efeito.

Esses fatores agrupam-se de forma solidária em situações de bom funcionamento - embora cada combinação específica seja exclusiva, e uma variedade infinita de combinações possíveis possa funcionar de maneira positiva. Um agrupamento é ainda mais resiliente quando reunido (desenvolvendo-se ao longo do tempo numa sociedade determinada), mas a ausência de um agrupamento que forneça apoio aumenta a dificuldade da tarefa, pois é extremamente difícil trazer alinhadas o complemento total das vertentes de apoio. Situações disfuncionais podem equivaler a uma armadilha estrutural que malogra os esforços de reforma jurídica. ${ }^{18}$ Essa é a concatenação do princípio de direito em ação. Muitos esforços de reforma jurídica são minados por um paradoxo tenaz: a população deve se identificar com a lei e respeitá-la, assim como respeitar os juízes, se o sistema jurídico funcionar corretamente, mas este deve funcionar corretamente se a população se identificar com a lei e respeitá-la e respeitar também os juízes.

Embora o foco desta discussão recaia sobre as reformas judiciais, os mesmos pontos se aplicam fortemente a todos os tipos de reforma jurídica. Considere o seguinte resumo sobre a reforma malsucedida das leis econômicas após o colapso do comunismo:

Na Europa Oriental, os principais favorecidos pelo subsídio externo foram as seis maiores empresas de contabilidade (the Big Six) do Ocidente, que elaboraram novas leis para o Leste Europeu e instruíram milhares de habitantes locais acerca do direito ocidental. As assembleias legislativas da Europa Oriental aprovaram as leis elaboradas no Ocidente, satisfazendo as condições de auxílio elaboradas pelo Ocidente, mas as novas leis tiveram pouco efeito sobre as regras de conduta vigentes. (EASTERLY, 2006, p. 64) 
Reformas jurídicas dessa natureza - em especial o transplante jurídico indiscriminado - normalmente fracassam, pois não são adaptadas às culturas e às circunstâncias jurídicas e econômicas locais: são, antes, enxertadas num ordenamento jurídico que padece de uma série de problemas sistêmicos e que, além disso, carece de recursos suficientes e de atores locais comprometidos com o sucesso do direito. ${ }^{19}$

Não se trata de uma visão fatalista. O desenvolvimento jurídico (e a regressão jurídica) ocorreu, muitas vezes, após uma variedade de percursos distintos, desde o crescimento orgânico ao transplante imposto ou voluntário, e não há nenhum acordo exclusivo ou padrão para um sistema jurídico funcional que atenda às necessidades de seus cidadãos. "Aquela 'condição prévia' que parece existir em quase todos os casos é a demanda nativa por reforma jurídica e judiciária, conduzida seja por uma elite (o padrão comum) ou por um amplo sentimento popular" (TROOPE, 2003, p. 393). Da concatenação do princípio de direito decorre que é essencial examinar os fatores circundantes para determinar que tipo de reforma é necessário e exequível de modo prático e lembrar que os fatores não legais importam para o sucesso das reformas, pelo menos tanto quanto os fatores legais. As perspectivas para um desenvolvimento jurídico bem-sucedido serão intensificadas por meio do estabelecimento de capacidades locais - pelo treinamento de membros da sociedade que se comprometerão com os esforços empregados na reforma jurídica a longo prazo e pelo apoio a esses membros - e do incentivo a orientações positivas em relação à lei (embora o sistema jurídico deva produzir resultados positivos para que isso se estabeleça). A maneira como se desenvolve um sistema jurídico, sua forma e seu caráter em uma determinada sociedade sempre é, fundamentalmente, uma questão local.

\section{Direito e capitalismo}

O desejo de facilitar o desenvolvimento econômico é a principal motivação por detrás da generosa atenção dada ao Direito e Desenvolvimento hoje. Parece que os sistemas jurídicos, nessa perspectiva, são um pré-requisito essencial para o desenvolvimento econômico sustentável. O afluxo maciço de recursos alocados ao Direito e Desenvolvimento na última década tem sido fornecido por instituições cuja principal missão é impulsionar o desenvolvimento econômico. ${ }^{20} \mathrm{O}$ desenvolvimento do direito se justifica, portanto, como meio para alcançar fins de desenvolvimento econômico. O pacote-padrão inclui leis sobre formação de sociedade, valores mobiliários, antitruste, operações bancárias, propriedade intelectual, transações comerciais, proteções para investidores estrangeiros e direitos de propriedade e execução do contrato. Essa foi a plataforma do Consenso de Washington, de reformas complacentes para com o mercado, ativamente promovida em todo o mundo nas décadas de 1980 e $1990 .{ }^{21}$ 
Uma designação mais precisa para essa corrente seria "direito e capitalismo", pois sua orientação é desenvolver regimes jurídicos adequados para participação na economia de mercado global. A queda do comunismo, em especial na União Soviética, com as subsequentes transições de muitas nações para economias de mercado, precipitou um clamor (dos vendedores e dos compradores jurídicos), na década de 1990, por reformas jurídicas consideradas necessárias ao capitalismo nacional e internacional. $\mathrm{Na}$ pressa de adotar o capitalismo global, ativos anteriormente possuídos pelo governo (companhias de serviços públicos, fábricas, recursos naturais, transporte público) foram vendidos à iniciativa privada, muitas vezes a baixos preços e para membros do próprio governo ou suas famílias, elevando o número de protestos contra a injustiça e a corrupção. Essa captura de ativos motivou demandas adicionais por melhores leis e instituições jurídicas. Além disso, a culpa pela crise financeira asiática de 1997 foi atribuída ao regulamento financeiro e à execução negligentes, reavivando a demanda por uma reforma jurídica de ordem econômica. ${ }^{22}$

Outra motivação para a mudança em relação ao direito foi o obstinado malogro em desenvolver grande parte das nações na África Subsaariana e na Ásia Central - o desesperador "um bilhão de pessoas pertencentes à base da pirâmide social" (COLLIER, 2007, p. 103), o Bottom Billion. Enquanto países ao redor do globo, principalmente a China e a Índia, progrediam de forma surpreendente em relação ao desenvolvimento econômico, aquelas nações desamparadas ficavam cada vez mais para trás. Cada fracasso tem seu próprio complexo de razões, mas a maioria desses países padeceu sob governos instáveis ou venais. Subsídios em dinheiro dados a tais países para financiar projetos de desenvolvimento econômico muitas vezes acabaram nas contas bancárias ultramarinas de funcionários do governo ou foram gastos na compra de armas para o exército (COLLIER, 2007). A melhoria do sistema jurídico proporcionou a esperança de que as restrições constitucionais e as leis anticorrupção mitigariam esse mau comportamento.

Mesmo aqueles países que experimentaram uma melhoria econômica repentina e intensa continuam a apresentar grandes quantidades de pobres, localizados nas zonas rurais ou agrupados em conjuntos habitacionais urbanos provisórios (como ocorre em Manila, Mumbai, Cidade do México). Posseiros não têm nenhum direito legal de propriedade em relação a seu domicílio, e muitos deles trabalham na economia informal (ou às escondidas); a criminalidade urbana é galopante. Acreditava-se que os direitos e a proteção jurídica ajudariam a melhorar suas condições de vida e perspectivas econômicas.

A função de apoio que o direito exerce no capitalismo tem sido um tema recorrente há mais de um século, com a contribuição inicial prolífica de Max Weber. ${ }^{23}$ Os direitos de propriedade incentivam a atividade produtiva, permitindo que as pessoas colham os frutos de seu trabalho. O direito contratual, por sua vez, faculta às pessoas a possibilidade de realizar transações de longe e ao longo do tempo, permitindo-lhes 
antever com segurança os custos e os benefícios das trocas propostas. Já o direito penal mantém a ordem social, trazendo segurança geral, resguardando as pessoas de terem de empregar esforços e recursos para proteger a si ou sua propriedade. Certeza, previsibilidade e segurança, de acordo com o exposto, são os benefícios essenciais que o direito prevê para a atividade econômica. Esse conjunto básico de ideias foi completado, na década de 1990, pelo surgimento da Nova Economia Institucional (NIE), conduzida pelo ganhador do prêmio Nobel, o historiador econômico Douglas North, o qual defendia que o desenvolvimento de instituições jurídicas, em especial a proteção da propriedade, é um acompanhante essencial do desenvolvimento econômico (NORTH, 1990).

Voz proeminente do sul, o economista peruano Hernando De Soto também ressaltou a importância dos direitos de propriedade no desenvolvimento. Ele observou, ainda, que, nos países em desenvolvimento, muitas propriedades não são oficialmente documentadas ou registradas, ou os documentos são obscuros, e, além disso, a escrituração é um processo dispendioso e demorado. Em consequência, a propriedade em questão não pode ser usada como caução para garantir empréstimos, as pessoas ficam menos propensas a melhorar a propriedade (temendo perdê-la), e o mercado para a propriedade é restringido de forma artificial. Portanto, grande parte da riqueza potencial e do capital nas sociedades em desenvolvimento encontra-se improdutivamente travado.

Parece ser uma verdade inequívoca que o direito facilita o desenvolvimento econômico. O Banco Mundial produziu estudos estatísticos detalhados os quais mostram uma correlação entre "o Império do direito" e uma série de indicadores de desenvolvimento. ${ }^{24} \mathrm{O}$ ex-presidente do Banco Mundial James Wolfensohn afirmou que a evidência empírica mostra uma relação causal grande e significativa entre o Império do direito aperfeiçoado e a renda das nações, o Império do direito e o letramento, e entre o Império do direito e a redução da mortalidade infantil. ${ }^{25}$ Devido a essa crença, o Banco Mundial realocou drasticamente seu financiamento do desenvolvimento. "Há trinta anos", observou o diretor jurídico da instituição, "o banco possuía 58\% de sua carteira em infraestrutura; hoje, reduziu-se para $22 \%$, ao passo que o desenvolvimento humano e a reforma institucional e jurídica representam $52 \%$ de nosso total dos empréstimos". 26

Não obstante, existem razões para se questionar a sabedoria dessa mudança. Embora estudos estatísticos tenham demonstrado uma correlação positiva entre Império do direito e Desenvolvimento econômico, ${ }^{27}$ tais resultados precisam ser lidos com cautela. O "Império do direito" não é uma medida fácil, e indicadores distintos têm sido usados. ${ }^{28}$ Ademais, as correlações encontradas não identificam as relações casuais subjacentes. ${ }^{29}$ É possível que o desenvolvimento econômico (inicialmente estabelecendo-se em fontes informais de segurança e certeza) ${ }^{30}$ talvez seja o que impele ou leva a uma melhoria no direito; ou talvez haja a possibilidade de que 
tanto o desenvolvimento econômico como o Império do direito sejam originados por um denso complexo de fatores subjacentes o qual explica sua coincidência. ${ }^{31}$ Ou, ainda, talvez diferentes situações ou estágios de desenvolvimento econômico e jurídico manifestem relações casuais diferentes - é fantástico imaginar que haja somente um modo de desenvolvimento econômico e jurídico que seja válido em todos os lugares e em qualquer tempo. As situações no Ocidente em que as instituições jurídicas evoluíram em sincronia com os avanços no capitalismo são radicalmente distintas daquilo que os países em desenvolvimento atualmente enfrentam na tentativa de saltar no mercado capitalista global, enquanto ainda criam os vários estágios (instáveis) de institucionalização das instituições jurídicas.

Tais possibilidades devem ser consideradas, pois, se estiverem corretas, investir dinheiro no desenvolvimento jurídico não resultará, necessariamente, no desenvolvimento econômico desejado. Um estudo recente do Banco Mundial afirmou que o crescimento do Império do direito é um dos meios "mais importantes" de aumentar a riqueza total $;^{32}$ um crescimento de 1\% no índice de Império do direito contribui mais para o capital intangível do que um aumento de $1 \%$ nos anos de escolarização. ${ }^{33}$ Se os dirigentes, apoiando-se nessa descoberta, transferirem verbas da escolarização para o desenvolvimento jurídico, cometeriam um sério erro, uma vez que os desenvolvimentos econômico e jurídico são ambos facilitados e dependentes de um conjunto substancial de cidadãos instruídos.

Os céticos a respeito da alegação de que o Império do direito é essencial para o desenvolvimento econômico são rápidos em assinalar que tal proposição é desmentida por eventos econômicos concretos. Se o "Império do direito" é concebido para incluir direitos de propriedade, execução de contrato e tribunais independentes que apliquem a lei, então se torna difícil enquadrar a conexão estabelecida com o fato de que os exemplos recentes mais espetaculares de desenvolvimento econômico - em especial a China _ ${ }^{34}$ não preenchem esses pré-requisitos jurídicos. ${ }^{35}$ Muito da propriedade produtiva durante o boom na China era de propriedade coletiva. As redes de relacionamento entre empresários são mais importantes para as transações do que o direito dos contratos. China, Coreia e Taiwan fizeram avanços econômicos iniciais ignorando os direitos de propriedade intelectual (produtos de engenharia reversa, venda de falsificações ou bens pirateados). ${ }^{36}$ As decisões judiciais na China estão sujeitas a revisão por autoridades políticas. Os juízes coreanos e taiwaneses, durante o período de boom, também estavam longe de ser independentes. ${ }^{37}$

Esses contraexemplos nos fazem lembrar que, para perceber a ligação com o desenvolvimento econômico, é necessário observar esferas diferenciadas de operação econômica e jurídica. A receita-padrão para o sucesso econômico no capitalismo global contemporâneo (no primeiro degrau de desenvolvimento econômico) é produzir bens em massa e a baixos custos para exportação. A fim de atrair investidores transnacionais que forneçam capital e tecnologia para instalações de produção, os 
países devem oferecer um amplo serviço de mão de obra disciplinada a baixos salários, com instrução básica, baixos impostos, uma infraestrutura de transporte adequada e proteções para o investimento estrangeiro. ${ }^{38} \mathrm{O}$ último fator pode ser atendido por meio de acordos para a resolução de litígios em cortes internacionais ou em arbitragem privada - ignorando o sistema de tribunal nacional - e por meio de garantias críveis oferecidas por funcionários do governo de que as instalações produtivas e os lucros não serão expropriados (COLLIER, 2007). Deve-se notar que a proteção contra o confisco de bens por parte do governo é mais uma questão de estabilidade política e credibilidade do que de restrições legais (as quais podem ser menosprezadas). As Zonas de Processamento de Exportação (ZPEs) têm atraído, por meio dessa fórmula, investimento para diversos países menos desenvolvidos.

Os países que proporcionam tais condições - oferecendo tipos específicos de auxílio jurídico que interessam aos investidores estrangeiros - podem passar por um rápido desenvolvimento econômico, mesmo se, em geral, o sistema jurídico não satisfizer os critérios do Império do direito. Os bons resultados de desenvolvimento do Leste Asiático, ocorridos em governos semiautoritários, demonstraram que "sistemas centralizados são capazes de criar um regime estável, previsível e, portanto, de confiança para os investidores, mesmo que a corrupção seja um componente do ambiente operacional" (HAGGARD; MACINTYRE; TIEDE, 2008, p. 212).

Estes contraexemplos expõem uma questão significativa facilmente ofuscada pela ênfase dada ao Império do direito. As funções que o direito prevê ao desenvolvimento capitalista - especialmente a segurança e a certeza - talvez possam ser desempenhadas por outros mecanismos formais ou informais, em determinados contextos sociais. ${ }^{39} \mathrm{O}$ trabalho de De Soto demonstra que as transações econômicas de fato ocorrem com base em formulários informais de propriedade, embora o autor defenda que seria melhor a legalização da propriedade. Além disso, os estudos sugerem também que, enquanto instituições jurídicas estáveis se correlacionam de maneira positiva com o desenvolvimento econômico, uma gama de diferentes regimes jurídicos importantes pode funcionar. ${ }^{40}$ Como demonstrado pela China, os bens imóveis não precisam ser mantidos ou alienados de forma privada com o intuito de serem usados produtivamente para fins econômicos. Por outro lado, estudos empíricos de projetos de escrituração (do tipo defendido por De Soto) mostram resultados confusos - às vezes tais projetos facilitam as atividades econômicas e, às vezes, não (DAVIS; TREBILCOCK, 2001; CROSS, 2002).

A variabilidade de sistemas jurídicos em conexão com o desenvolvimento econômico é ainda outra iteração da concatenação do princípio de direito, desenvolvido em relação ao desempenho econômico. Esse princípio é construído na NIE, a qual reconhece que as instituições jurídicas operam no interior de e são apoiadas por complexos sociais e culturais locais de normas e crenças - o desempenho econômico é, em última análise, um produto dessa totalidade. A NIE é frequentemente citada 
para mostrar que o direito é necessário para o desenvolvimento econômico, mas isso ignora o ponto mais fundamental, formulado por North (1994):

É a mescla de regras formais, normas informais e características de exequibilidade que configuram o desempenho econômico. Enquanto as regras podem ser modificadas da noite para o dia, as normas informais normalmente se alteram apenas de forma gradual. Haja vista que são as normas as responsáveis por proporcionar 'legitimidade' a um conjunto de regras, uma transformação revolucionária jamais será tão revolucionária quanto o anseio de seus defensores, e o desempenho será diferente em vez de previsto. E as economias que adotam as regras formais de outra terão características de desempenho bastante diferentes em relação à primeira economia, devido às normas informais distintas e à execução. (p. 366)

Outro colaborador da NIE, Oliver Williamson (2000) enfatiza de maneira similar que instituições jurídicas formais operam num nível mais fundamental de "enraizamento social. Esse é o lugar onde normas, costumes, modos, tradições etc. se localizam" (p. 596). As forças e as influências nesse nível mais fundamental se modificam lentamente, ao longo de décadas, por caminhos que se esquivam de esquemas deliberados ou manipulações.

Uma paira gira em torno da atual popularidade do Império do direito para o desenvolvimento. Voltar-se ao Império do direito a fim de superar fracassos no desenvolvimento econômico pode significar, na verdade, a substituição de um conjunto de problemas aparentemente intratável por outro ainda mais complicado. A melhoria do direito depende de uma multiplicidade de condições sociais, culturais, políticas e econômicas de apoio - em termos comparativos, o estabelecimento de ZPEs parece simples.

A crise econômica recente ocasionada pelas práticas arriscadas (e altamente influentes) de empresas financeiras dos Estados Unidos (bancos, casas de investimento, companhias de seguros) cria uma ironia adicional. O presidente brasileiro Luis Inácio Lula da Silva (apud PHILLIPS, 2009) observou, numa viagem recente à Índia, que "é inaceitável que nós tenhamos de pagar pela irresponsabilidade de especuladores que transformaram o mundo num cassino gigantesco e, ao mesmo tempo, que eles nos deem lições de como nós devemos governar nossos países. Nós somos vítimas de uma crise econômica gerada pelos países ricos" (p. 224). Além da ironia de que, em vista dos acontecimentos recentes, foram os regulamentos e a execução ocidentais que se revelaram inadequados, uma séria reflexão é conduzida acerca da hipótese de o estilo asiático neomercantilista e o nacionalismo econômico - que incluem o controle pelo Estado dos recursos naturais e a condução estatal dos fundos de investimento, bem como uma indústria voltada à exportação combinada a 
vários tipos de barreiras de importação que visam proteger a produção industrial nacional - serem ou não superiores ao capitalismo de mercado ocidental e o seu pacote jurídico de apoio voltado ao rápido desenvolvimento econômico (ao menos em estágios iniciais) (PHILLIPS, 2009). Afinal, as nações ocidentais também lançaram mão de estratégias mercantilistas em seus estágios iniciais de desenvolvimento econômico (REINERT, 2007). Em The Growth Report, um estudo de 2008 publicado pelo Banco Mundial, constatou-se que o elemento comum às histórias bem-sucedidas de desenvolvimento dos últimos vinte anos é a presença de um Estado forte e voltado ao desenvolvimento.

\section{O pacote Progressista do Direito e Desenvolvimento}

A terceira corrente presente no Direito e Desenvolvimento se move para além do mero desenvolvimento econômico, também abarcando outras reformas integradas (CAROTHERS, 2009). Uma abordagem abrangente do desenvolvimento foi vigorosamente promovida por Amartya Sen (2000):

A alegação aqui não se refere tanto ao fato de que, digamos, o desenvolvimento jurídico influencia de forma causal o desenvolvimento simplesmente, mas, sim, ao fato de que o desenvolvimento como um todo não pode ser considerado separadamente do desenvolvimento jurídico. Com efeito, nessa perspectiva, a ampla ideia de desenvolvimento é uma relação funcional que reúne interesses distintos no tocante ao desenvolvimento nas esferas econômica, política, social, jurídica, entre outras. Isso é mais do que interdependência causal: envolve uma conexão constitutiva no conceito de desenvolvimento como um todo. (p. 8)

A visão de Sen inclui o desenvolvimento equitativo (uma distribuição justa da riqueza), uma rede de segurança social adequada, proteção contra a violência e a insegurança, democracia e liberdades políticas, uma mídia livre e direitos da mulher - tudo com a finalidade de auxiliar no aumento das capacidades e liberdade das pessoas. Isso coloca em questão o próprio significado de "desenvolvimento" - desafiando as suposições de que isso possa ser entendido ou mensurado exclusivamente em termos econômicos.

Quando o ritmo das reformas econômicas neoliberais retrocedeu, na virada do século, o Banco Mundial (2002, apud SANTOS, 2006) adotou gradualmente uma visão mais ampla: "o Império do direito é essencial para um desenvolvimento econômico equitativo e uma redução sustentável da pobreza [...]. Indivíduos vulneráveis, incluindo mulheres e crianças, estão desprotegidos da violência e de outras formas de abuso que agravam as desigualdades" (p. 276). As iniciativas do Direito e Desenvolvimento 
começaram a lidar com um pacote mais amplo, que incluía "desenvolvimento econômico, redução da pobreza, democracia, direitos humanos, devido processo legal, equidade etc.". 41

Em contraste ao elenco conservador da corrente direito e capitalismo anteriormente discutida, a corrente Direito e Desenvolvimento, mais ampla, é decididamente de esquerda e progressista. A ênfase no direito privado da primeira corrente conferida aos direitos de propriedade e ao direito comercial sucumbe a um maior interesse, na segunda corrente, em relação ao direito público - às proteções constitucionais e aos direitos políticos e civis. Uma tensão patente espreita logo abaixo da superfície dessas respectivas ênfases. Os defensores de uma perspectiva mais ampla são céticos quanto à disseminação descontrolada do capitalismo global: suscitam preocupações acerca de suas consequências humanas e ambientais adversas, bem como duvidam da sua imparcialidade na seleção de vencedores e vencidos e nas distribuições de benefícios.

A confusão surge porque tanto conservadores quanto progressistas estabelecem seus programas sob a égide do desenvolvimento do "Império do direito". No contexto de desenvolvimento, o Império do direito tem sido identificado com direitos de propriedade, execução de contratos, baixas taxas de criminalidade, corrupção mínima, judiciários com bom funcionamento e independentes, formalismo jurídico, limites legais a funcionários do governo, democracia, direitos civis e direitos previdenciários. ${ }^{42}$ Esse vasto uso da expressão ameaça esvaziá-la de seu significado. Um estudo que comparou as variáveis do Império do direito comumente listadas constatou um "nível relativamente baixo de correlação tanto dentro das categorias como entre elas" (HAGGARD; MACINTYRE; TIEDE, 2008, p. 222), e, em alguns casos, elas foram correlacionadas negativamente. Tais resultados sugerem que fatores distintos, ou talvez inconsistentes, estão sendo mensurados em vários estudos que pretendem avaliar os níveis de consolidação do "Império do direito".

Há um elemento de crença e outro de oportunismo no pacote progressista de Direito e Desenvolvimento. O elemento de crença é a confiança ou esperança de que o pacote democrático-liberal seja consistente. De acordo com essa crença, existe um círculo que se reforça mutuamente, no qual o Império do direito gera bem-estar social e o capitalismo, por sua vez, gera direitos liberais. As setas causais presumivelmente seguem em todas as direções, cada uma auxiliando a outra, com o Império do direito tendo grande peso e responsabilidade ao todo. ${ }^{43}$ Essa convicção ajuda a explicar o anseio dos Estados Unidos em promover a reforma do Império do direito na China, na esperança de que a reforma jurídica possa naturalmente "infiltrar-se em outras áreas" (STEPHENSON, 2006, p. 200), incluindo, consequentemente, uma maior democracia e os direitos humanos.

Contudo, o elemento oportunista surge quando aqueles que não compartilham dessa crença argumentam estrategicamente que sua própria parte predileta do pacote 
pode ser aprimorada pegando uma carona no vagão do Império do direito. Dentro desse espírito, David Trubek (2006), um estudioso de longa data do Direito e Desenvolvimento abertamente cético em relação ao Império do direito, não obstante incita que "intelectuais progressistas devem se engajar de maneira construtiva na iniciativa do Império do direito" (p. 93-4), visto que fornece um veículo de luta aos objetivos progressistas.

A promessa de que o desenvolvimento do Império do direito traria esses outros benefícios não foi corroborada pelos eventos, ao menos não a esse extremo. Como Carothers (2009) assinala, China e Rússia adotaram de forma fragorosa o Império do direito ao mesmo tempo que controlavam rigidamente a democracia e os direitos; e os dois países não estão sozinhos. "Em todos esses países," observa o autor, “os governantes autoritários descobriram que o Império do direito funciona bem enquanto propósito alternativo à democratização, não como algo que a complementa, mas, sim, como algo que irá auxiliar a preservar o regime autoritário ou semiautoritário" (p. 54). O Império do direito - o direito estabelecendo limites ao governo - pode ser facilmente transposto para império pelo direito - direito como instrumento de regime de governo (STEPHENSON, 2006). Alguns países da América Latina combinam eleições democráticas, executivos poderosos, tribunais fracos e ordenamentos jurídicos severos (DODSON, 2002). Um estudiosos latino-americano fez "a pesarosa observação de que, por vezes, o Império do direito (ou, em todo caso, a retórica do Império do direito) tem sido colocado a serviço de regimes autoritários" (O’DONNELL, 2004, p. 45).

A fé inquebrantável nos tribunais como último baluarte de liberdade, democracia e direitos também padeceu com reiteradas decepções. Em um esforço de promover a promulgação de um novo código penal na Rússia, o qual previsse o devido processo legal e oferecesse proteções justas para os réus durante os julgamentos, o governo norte-americano sediou conferências e seminários de treinamento para muitos juízes e advogados (entre os "milhares") e pagou para que juízes russos participassem de seminários e jantares nos Estados Unidos na esperança de que se tornassem defensores da reforma. Contudo, quando o código entrou em vigor, a maioria dos juízes e advogados "integrou parte do coro que se opôs à reforma" (SPENCE, 2006, p. 227). Um programa patrocinado pela Agência Norte-Americana para o Desenvolvimento Internacional em El Salvador, com o intuito de melhorar a administração judicial e reformar o sistema de justiça penal, "fracassou" por conta da "forte resistência à reforma" por parte dos juízes (DODSON, 2002, p. 204). As reformas no Brasil foram implementadas para conceder aos juízes independência institucional substancial, incluindo proteções contra remoção, além de salários garantidos; controle sobre pessoal, disciplina e também sobre seu orçamento. Os observadores descobriram que "um grande aumento da autonomia do judiciário levou a um nepotismo desmedido e a outras oportunidades de corrupção" (p. 215). 
O judiciário foi visto como um "enclave privilegiado” (p. 215) largamente desprezado pelo público.

Os resultados dos esforços de reforma dependem de como tais esforços interagem com o complexo de fatores circundante - a concatenação do princípio de direito -, sendo que isso pode tomar qualquer direção. O resultado depende das visões culturais circundantes; depende dos incentivos em jogo (quem ganha ou perde dinheiro, status ou poder); e depende de muitos outros fatores. Não há duvida de que o Império do direito, a democracia, os direitos civis e o capitalismo de bem-estar social podem existir de modo que se auxiliem mutuamente, como o fazem em democracias liberais. Nada inerente ao Império do direito, no entanto, leva à reprodução desse arranjo nos países-alvo de projetos de Direito e Desenvolvimento, países os quais apresentam uma dinâmica social, cultural, econômica, política e jurídica imensamente diferente. Os direitos humanos e a democracia, quando levados a sério, dependem do Império do direito como forma de apoio; mas o Império do direito, por si só, não produz automática ou necessariamente os direitos humanos e a democracia. ${ }^{44}$

As pessoas envolvidas na iniciativa do Direito e Desenvolvimento já sabem disso. Poucas pessoas familiarizadas com as condições reais dos países-alvo podem acreditar esperançosamente que o Império do direito por si só possua o poder de refazer as sociedades em todo o mundo, a fim de que elas se assemelhem à visão progressista almejada. Talvez seja óbvio, embora ainda digno de nota, que muito da atividade e do discurso do Direito e Desenvolvimento - tanto nas variantes conservadoras como nas progressistas - seja a advocacia. É nela que os elementos de crença e oportunismo se encontram.

\section{A iniciativa do Direto e Desenvolvimento}

A análise anterior examinou os problemas dos destinatários das atividades do Direito e Desenvolvimento. Haja vista que o Direito e Desenvolvimento é mais bem compreendido não como um "campo", mas como uma coleção de atividades financiadas e promovidas por países capitalistas avançados, conforme defendido anteriormente, é igualmente essencial investigar minuciosamente os remetentes.

As atividades de desenvolvimento jurídico ascenderam no início da década de 1990, quando o Banco Mundial adotou a construção do Império do direito. No entanto, antes que isso viesse a acontecer, um grande obstáculo teria de ser superado. Uma limitação específica em relação aos gastos consta no instrumento de contrato do Banco Mundial (o documento constitutivo que criou e controla o Banco): "Empréstimos feitos ou garantidos pelo Banco servirão, exceto em circunstâncias especiais, a propósitos de projetos específicos de reconstrução ou desenvolvimento”. ${ }^{45}$ Uma outra cláusula pró́be o Banco de se engajar em atividades políticas: "O Banco e seus funcionários não deverão interferir nos assuntos políticos 
de qualquer membro, nem serem influenciados em suas decisões pelo caráter político do membro ou membros envolvidos. Apenas considerações de ordem econômica serão relevantes em suas decisões". ${ }^{46}$ Essas disposições eram adequadas ao propósito para o qual o Banco Mundial - oficialmente denominado Banco Internacional para Reconstrução e Desenvolvimento - fora criado, no meado da década de 1940, em meio aos destroços trazidos pela Segunda Guerra Mundial, o de auxiliar no financiamento da recuperação econômica. ${ }^{47}$

No início da década de 1990, o então conselheiro geral do Banco Mundial, Dr. Ibrahim F. I. Shihata, emitiu uma série de opiniões jurídicas que reescreveram efetivamente os limites estabelecidos no instrumento de contrato restritivos do financiamento a projetos de desenvolvimento econômico, para permitir, de forma mais ampla, o financiamento de projetos relativos ao Império do direito. ${ }^{48}$ Ele sutilmente conseguiu isso na seguinte passagem: "Em circunstâncias normais, os empréstimos e garantias do Banco destinam-se ao financiamento de projetos específicos, no sentindo amplo do termo, o que, em minha opinião, inclui todos os fins produtivos bem definidos, sejam estes fornecidos diretamente (como na indústria e na agricultura) ou indiretamente (como em infraestrutura, desenvolvimento institucional, serviços sociais etc.)" (EFFROS, 2001, p. 1345). Essa inclusão do apoio ao "desenvolvimento institucional" abriu as portas para o desenvolvimento jurídico.

O dinheiro do Banco Mundial, a partir de então, começou a fluir em direção aos projetos de Império do direito. Sem a atuação de Shihata, tais projetos não teriam sido possíveis com a ausência de uma emenda ao instrumento de contrato por parte dos países signatários. Isso não deve ter sido fácil de conseguir, uma vez que o Banco e as suas atividades têm sido controversos por muito tempo.

Existe uma incongruência desconcertante no fato de que os projetos voltados para a construção do Império do direito são atualmente financiados em grande escala, somando milhões de dólares, graças a uma emenda efetiva na "constituição" do Banco, forjada por seu melhor advogado (embora outros na organização indubitavelmente tenham contribuído para o valor dos projetos de reforma jurídica). ${ }^{49}$ Os partidários de Shihata aclamam sua "flexibilidade de interpretação", considerando-a necessária para manter as atividades do Banco em sincronia com a mudança dos tempos (EFFROS, 2001). Talvez assim o seja, mas ela é duvidosa enquanto uma questão de fidelidade ao direito. Não obstante esse início desfavorável, a iniciativa de Shihata provou ser um sucesso retumbante, ao assegurar subsídio financeiro para as atividades de desenvolvimento jurídico.

Quando as portas se abriram para a reforma do Império do direito, inicialmente com uma concentração limitada aos direitos de propriedade, ao direito comercial e à reforma jurídica, esta última foi sendo gradualmente ampliada para incluir aspectos do pacote de desenvolvimento progressista. Em razão da expansão do alcance dos projetos de Império do direito e com o financiamento de projetos econômicos cada 
vez mais condicionados à aceitação de exigências do Império do direito, essas ações se colocam em oposição à proibição do Banco à interferência em assuntos políticos das nações favorecidas.

Tal evento tem sido relatado não para difamar os motivos de Shihata, mas, antes, para ilustrar de forma concreta que a promoção do Império do direito é o resultado de esforços de indivíduos - bem intencionados e dedicados - que o deslocaram agressivamente para o centro da pauta de desenvolvimento. Advogados propõem, organizam e executam os projetos - consultores independentes de Direito e Desenvolvimento, fundadores ou empregados de ONGs, equipes de advogados em organizações de desenvolvimento e professores de direito. Do ponto de vista dos advogados, os projetos de Império do direito sem dúvida valem a pena. Graças ao prestígio inigualável que o Império do direito goza no discurso político global contemporâneo, as fontes de financiamento estão deslumbradas com seus projetos, fornecendo, assim, subsídio financeiro para tais atividades. Além do fascínio, o trabalho do Direito e Desenvolvimento proporciona viagens a terras exóticas, ao mesmo tempo que engaja em boas ações, auxiliando àqueles que necessitam. De modo superficial, parece ser algo notável.

Mas os participantes desse empreendimento expuseram suas falhas internas. Haja vista que os projetos são conduzidos e executados por advogados, eles naturalmente se concentram naquilo com que os advogados estão familiarizados - juízes, advogados, polícia e códigos legais. Conforme enfatizado por um crítico da reforma agrária na África, é essencial considerar a ação dos advogados - "as atividades empresariais dos profissionais jurídicos” (MANJI, 2006, p. 82) - na configuração e na orientação das atividades de Direito e Desenvolvimento. "Diferentemente dos profissionais do desenvolvimento que dominam muitas outras áreas de desenvolvimento, vários profissionais ocidentais que apoiam o Império do direito têm pouca ou nenhuma experiência prévia em sociedades subdesenvolvidas ou transicionais" (GOLUB, 2006, p. 295). Não ocorreria de modo imediato aos advogados que o próprio direito pudesse ser uma parte do problema, ou que uma solução mais eficaz pudesse existir em outra parte; eles nem saberiam facilmente onde olhar para encontrar alternativas ao direito. Muitas vezes, as pessoas enviadas são inexperientes ou desinformadas a respeito da maneira como o direito funciona em situações radicalmente diferentes. "Juízes seniores, jovens advogados ambiciosos ou policiais aposentados são geralmente colocados em posições de planejamento e gerenciamento de projetos, aconselhando as contrapartes locais ou ministrando treinamento" (PIRON, 2006, p. 294).

Outra falha comum refere-se ao fato de que as pessoas que realizam tais projetos frequentemente não conhecem muito as circunstâncias locais. Pode levar de seis meses a um ano de convívio numa sociedade para que um forasteiro adquira certo entendimento da dinâmica sócio-político-cultural, estabelecendo confiança e relacionamentos 
que ajudarão no processo de implementação. ${ }^{50}$ Um coordenador do projeto de império de direito revelou, no entanto, que em "dez anos de recrutamento e organização de consultores [...] tive, em geral, de batalhar para conseguir permissão para oferecer a eles mais de dois dias de preparação" (CHANNELL, 2006, p. 150). "Não é surpreendente, portanto, que muitos desse consultores se mostrem insuficientemente preparados para o cenário específico, embora sejam bem versados no assunto de sua especialidade" (p. 150). A rotatividade de pessoal que ocorre nas agências financiadoras e entre profissionais da área rotineiramente retiram pessoas que aprenderam a configuração da situação local e desenvolveram relações sociais, substituindo-as por pessoas que necessitam começar tudo de novo, adquirindo familiaridade e contatos (PIRON, 2006).

Projetos conduzidos dessa forma apresentam, desde o início, uma chance de sucesso drasticamente reduzida. Um profissional veterano esclareceu a falha fundamental apreendida pela concatenação do princípio de direito:

Especialmente durante o desenvolvimento do projeto, quando a própria natureza deste é decidida, muitas agências contam com consultores visitantes em vez da equipe local. Isso pode levar a uma análise superficial a respeito do que aflige um sistema jurídico e que assuntos jurídicos confrontam os desfavorecidos. Em termos mais brandos, uma sociedade vista de um hotel é muito diferente daquela vivenciada no seu dia-a-dia. (GOLUB, 2006, p. 130)

Problemas adicionais são criados em decorrência da maneira como os projetos são financiados, concebidos e imputados. ${ }^{51}$ Instituições doadoras, agências de desenvolvimento ou ONGs têm conduzido programas coexistentes nos mesmos países, sem coordenação ou partilha de conhecimento (CHANNELL, 2006; PIRON, 2006). O dinheiro vem em grandes lotes, que precisam ser gastos preferencialmente (ou revertidos) em algo concreto para ostentar (daí a simpatia por conferências chamativas), enquanto é mais difícil a obtenção de um fluxo contínuo de financiamento para projetos de maior duração (PIRON, 2006; GOLUB, 2006). Muitos projetos apoiados pelos Estados Unidos (através do USAID) são administrados por organizações privadas e com fins lucrativos. O processo de licitação de projetos, com grandes quantias em jogo, desencoraja a inovação (planos arriscados ou não postos em prática são menos suscetíveis de serem selecionados) e promove o sigilo no seio da comunidade de consultoria competitiva (CHANNELL, 2006). Os pedidos feitos pelas agências de desenvolvimento para doações adicionais de governos ou fontes de financiamento são amparados por exemplos de êxito do passado. Um crítico afirmou que "a tendência em alegar um enorme impacto nos projetos de reforma jurídica e judiciária é bastante difundida" (TROOPE, 2003, p. 409), embora seja difícil avaliar 
os benefícios reais. Pode-se verificar mais facilmente se os projetos concretos de assistência técnica - por exemplo, a organização de seminários de treinamento para advogados e juízes, a informatização do sistema judiciário - foram concluídos com êxito no final do período do projeto, mesmo quando as melhorias reais alcançadas na realização da justiça são mínimas. Ao avaliar tais atividades, é necessário ter em mente que "a reforma jurídica é um negócio" (CHANNELL, 2006, p. 153).

Tal como indicado no início, poucas pessoas envolvidas parecem considerar que esses projetos funcionem em um sentido mais profundo, ao menos não de forma aparente. Pequenas melhorias no funcionamento institucional podem ser alcançadas, mas, em geral, o sistema jurídico encara esses esforços como algo impassível. Devese lembrar que, de forma similar, muitos projetos de desenvolvimento econômico fracassaram em apresentar resultados (EASTERLY, 2006). De fato, os repetidos fracassos dos esforços empregados na promoção do desenvolvimento econômico contribuíram para induzir a mudança de foco para o desenvolvimento jurídico, com base na teoria de que o desenvolvimento econômico estava sendo inibido pela ausência de uma infraestrutura jurídica facilitadora.

Logo, por que os projetos de Império do direito, com seus resultados insignificantes, continuam a receber subsídios financeiros generosos? O "Império do direito" é intangível e não pode ser apontado como uma fábrica destruída. As fábricas possuem planos arquitetônicos, são construídas num determinado período e obtêm êxito como empreendimento, ou então fecham suas portas. Por outro lado, o Império do direito não possui projeto nem estrutura padrão e, além disso, não é algo que possa ser constituído sob encomenda. Não existe nenhum calendário para se estabelecer o estado de direito, afora vagas referências a décadas ou gerações Os julgamentos acerca do valor e da eficácia dos projetos de Império do direito podem, assim, ser protelados indefinidamente.

\section{OS RISCOS DE TRANSPLANTAR O CONFRONTO DE IDEIAS}

Tal como foi indicado há pouco, os projetos de reforma jurídica são dominados pela perspectiva do advogado. O rótulo "Direito e Desenvolvimento", reforçado pela atual popularidade da bandeira do império de direito, reforça a orientação dada pelo advogado. Isso cria cegos em situações nas quais a melhor alternativa pode estar fora das instituições jurídicas.

Outra forma de cegueira surge no plano das ideias teóricas. As duas tensões antagônicas presentes no discurso do Direito e Desenvolvimento - direito e capitalismo, o pacote progressista - refletem diretamente ideias concorrentes de conservadores e liberais (respectivamente) das sociedades capitalistas ocidentais. Essas "guerras palacianas do norte”, como colocado por Garth (2002, p. 393), estão sendo exportadas para o sul e se desenvolvendo aí. Conhecidos adversários do norte debatem 
sobre o mesmo conjunto de ideias em seus países enquanto transferem o campo de batalha para o terreno do Direito e Desenvolvimento.

Esses protagonistas sinceros e motivados cometem um erro grave ao não prestar atenção às consequências adversas que poderiam resultar das principais diferenças subjacentes entre sociedades exportadoras e receptoras. Um exemplo proeminente de tal cegueira de ambos os lados será oferecido para ilustrar a questão.

De grande importância na pauta dos adeptos conservadores do direito e capitalismo é a ideia de que os países em desenvolvimento precisam escriturar a propriedade e permitir que esta seja livremente alienada; isso possibilitaria empréstimos bancários para que as pessoas se engajassem em atividades empreendedoras, utilizando a terra como garantia. ${ }^{52}$ Além disso, as pessoas fariam melhorias na propriedade, aumentando seu valor e a conduzindo a usos econômicos mais produtivos. Essa é a maneira pela qual o capital se torna disponível no Ocidente. Contudo, as coisas funcionam de maneira diferente em outros lugares. Em muitas sociedades, a propriedade é concebida e controlada de várias maneiras que não correspondem à posse absoluta pelos indivíduos. Nessas sociedades, membros de clãs e famílias detêm competências diferenciadas para usar a terra, cruzá-la, pastoreá-la, colher seus frutos, cultivá-la, e os demais devem ser consultados a respeito do que ocorre na terra. O processo de escrituração da propriedade, por sua vez, inevitavelmente extinguirá muito disso (os bancos não favorecem garantias onerosas).

Mas as consequências adversas são potencialmente piores do que isso. Em muitas sociedades, a vida da comunidade se assenta na terra e gira em torno dela de um modo que as sociedades ocidentais, desenraizadas, há muito esqueceram. Ao se permitir que a terra seja tomada e organizada pelos bancos, as relações sociais necessariamente serão perturbadas. No contexto ocidental, caso se torne inadimplente em relação ao pagamento de um empréstimo, você perderá sua casa; nessas sociedades, toda a vida social da comunidade será alterada ${ }^{53}$ e as pessoas perderão sua principal forma de segurança social. Além disso, a posição das mulheres será adversamente afetada, pois as reivindicações pela posse da terra em muitas culturas (destarte escritura jurídica) favorecem os homens. ${ }^{54}$ Ademais, a distribuição e a utilização da terra também mudarão, inevitavelmente, acumulando nas mãos de compradores abastados, ao passo que outros perderão a posse, o que acoasionará mais deslocamentos. Consequências adversas também acompanharão a escrituração da propriedade nas enormes cidades de construções precárias, nos guetos ou nas favelas que atualmente abarrotam os principais centros urbanos pelo mundo. Os posseiros que detêm escrituras perderão a propriedade ao se tornarem inadimplentes com relação ao pagamento de seus empréstimos, ficando, portanto, sem lar, ou se mudando para casas de parentes já populosas; compradores perspicazes colecionarão propriedades em vendas judiciais de bens hipotecados, aumentado suas propriedades de terra. Não se deve esquecer que na noção de escrituração está 
implícito - adicionalmente às vantagens que a escrituração traz - que a posse da terra será perdida e redistribuída.

Essas possíveis consequências deverão ter influência considerável sobre os benefícios econômicos que aparentemente resultarão da disseminação da posse privada de propriedade. Um advogado articulado, Kenneth Dam (2006), reconhece que as sociedades de propriedade comunal passarão por mudanças significativas de escrituração, mas relata brevemente que a mesma transformação também ocorreu no início da história do Ocidente, sendo que a situação melhorou por lá. As populações dos países em desenvolvimento, compostas por muitas pessoas que não possuem qualquer identificação com os modos ocidentais, podem não achar isso tranquilizador. A (não) analogia de Dam em relação aos direitos de propriedade no Ocidente também falhou em estimar as principais implicações resultantes da introdução (súbita) não evolutiva de sistemas de taxa simples de registro de escritura em contextos repletos de regras consuetudinárias sobre a propriedade amplamente reconhecidas. O resultado é criar uma situação com múltiplos conflitos em potencial e sistemas de normas concorrenciais, ${ }^{55}$ produzindo maior incerteza em relação aos direitos de propriedade e potencial para utilização oportuna de tais sistemas. ${ }^{56}$

Os habitantes locais devem ao menos ser inteiramente informados e consultados sobre as consequências sociais adversas da campanha para escrituração da propriedade. As pessoas devem ponderar acerca do tipo de desenvolvimento que almejam e o custo disso para as suas vidas e a comunidade.

A esquerda radical, por sua vez, comete um equívoco semelhante, ao também transferir suas hipóteses teóricas. Nas décadas de 1970 e 1980, teóricos jurídicos críticos de escolas de direito de elite nos Estados Unidos se engajaram numa crítica sistemática do "liberalismo jurídico". Seu argumento básico era de que o Império do direito operava sob o pretexto da neutralidade, a qual esconde o fato de que o direito mantém uma ordem social injusta a serviço da elite. ${ }^{57}$ Os teóricos jurídicos críticos foram especialmente mordazes acerca do formalismo jurídico, criticado por ser uma falsa alegação de aplicação objetiva da lei, quando, na verdade, as normas jurídicas dão aos juízes um espaço substancial para manobras. Eles afirmam ainda que os juízes formalistas são ou iludidos ou enganadores. Iludidos, caso argumentem mecanicamente, porque possuem, na realidade, liberdade substancial; enganadores, quando se escondem detrás do raciocínio formalista vinculado a normas, para atingirem os fins preferidos. O teórico jurídico crítico David Trubek, voz proeminente no Direito e Desenvolvimento por décadas, além de outros, conduziu esse ceticismo e o antagonismo em relação ao formalismo jurídico no contexto do Direito e Desenvolvimento. ${ }^{58}$

Mais uma vez, isso ignora uma diferença crucial. Embora seja saudável expor os exageros do formalismo jurídico nos sistemas jurídicos ocidentais em que o direito funciona razoavelmente bem, exportar o ceticismo referente ao formalismo legal 
para as sociedades em que o direito mal funciona é uma questão totalmente diferente. Visões excessivamente céticas do formalismo jurídico podem ainda impedir que um sistema jurídico decole. Um ordenamento jurídico não pode funcionar se a própria noção de vinculação a normas é entendida como fraude. Na ausência de quaisquer restrições legais, o poder possui seus meios, e a massa impotente de pessoas nos países em desenvolvimento terá pouca proteção.

Em ambos os exemplos precedentes, o da direita e o da esquerda, respectivamente, as ideias teóricas que se desenvolveram nos contextos ocidentais apresentam implicações muito diferentes quando trazidas e postas em prática em contextos de desenvolvimento. Isso é o que a concatenação do princípio de direito aconselha, e qualquer um que falhe em prestar atenção a isso inevitavelmente provocará consequências inesperadas e frequentemente indesejadas.

Os teóricos e profissionais do Direito e Desenvolvimento devem estar disciplinados pelas últimas cinco décadas dessa atividade. Após uma história contínua de resultados incertos, a humildade está em ordem. O que a humildade esconde é que a atitude norteadora no Direito e Desenvolvimento deve se pautar não apenas pela realização boas ações por meio do direito, mas, e talvez principalmente, por não causar nenhum dano via direito.

\section{7 “Direito e Desenvolvimento" nÃo É Desenvolvimento JuRídico}

No início do presente ensaio, afirmou-se que seria melhor não considerar o Direito e Desenvolvimento como um “campo". O propósito não era provocar um debate estéril acerca da sua qualificação ou não para tal designação - qualquer coisa pode constituir um “campo" se um número suficiente de pessoas considerá-lo como tal -, mas ajudar a realçar uma distinção nítida entre o "desenvolvimento jurídico", que ocorre em toda parte e o tempo todo, sem que haja qualquer rótulo especial, e o "Direito e Desenvolvimento". Sugeriu-se que o Direito e Desenvolvimento é mais bem compreendido enquanto um rótulo que atribuímos a inúmeros projetos financiados e realizados por um conjunto de organizações de desenvolvimento visando a países rotulados como economias capitalistas insuficientemente avançadas, ou desprovidos de peculiaridades de democracias liberais.

Desenvolvimento jurídico não é o mesmo que "Direito e Desenvolvimento" uma distinção que a última frase tende a ocultar. Para compreender isso, imagine como as coisas seriam se todos os projetos atuais de Direito e Desenvolvimento pelo mundo fossem interrompidos - imediatamente.

Em aspectos centrais, muito pouco mudaria. As instituições jurídicas em todos esses países dariam prosseguimento ao que elas fazem. Os atores jurídicos se ocupariam com suas atividades de consolidação do direito numa base contínua. Esses sistemas jurídicos padeceriam de muitas falhas, como acontece em todos os ordenamentos jurídicos. 
Os atores inseridos nessas sociedades - governo, empresas, organizações, indivíduos - continuariam a interagir com o sistema jurídico da forma que o fazem usualmente (invocando-o, evitando-o, aderindo a ele, tentando controlá-lo ou usá-lo em seu benefício). Os atores jurídicos e não jurídicos instigariam e estimulariam o ordenamento jurídico em relação às demandas que surgem dentro da sociedade. Esse é o processo dinâmico e em curso do desenvolvimento jurídico que ocorre em toda sociedade organizada (supondo a existência de, pelo menos, um sistema jurídico que funcione minimamente).

Isso não quer dizer que nenhuma consequência resultaria com o fim do Direito e Desenvolvimento. O dinheiro que hoje se destina a projetos - vários bilhões de dólares desde 1990 - desapareceria, juntamente com a pequena legião (consideravelmente dispersa) de profissionais de Direito e Desenvolvimento. Quando repartida entre cada país ao longo do tempo, essa quantia aparentemente elevada de dinheiro é menos impressionante. Para os grandes países, a retirada desse dinheiro dificilmente teria qualquer impacto no funcionamento diário do sistema. Para países pequenos ou muito pobres, a perda financeira seria sentida, mas as consequências de tal perda dependeriam daquilo em que o dinheiro proveniente do Direito e Desenvolvimento estava sendo gasto. Os vencimentos dos funcionários do judiciário raramente são abrangidos pelo financiamento proveniente do Direito e Desenvolvimento, de modo que os ordenamentos jurídicos dos países beneficiários continuariam a operar como antes; mas certos projetos técnicos onerosos, como a informatização, não seriam realizados. Haveria menos seminários de formação jurídica conduzidos por estrangeiros, menos conferências, bem como menos viagens ao exterior voltadas a funcionários públicos locais.

Outra mudança crucial refere-se ao fato de que todos os esforços de reforma do sistema jurídico - no decurso habitual do desenvolvimento jurídico - seriam propostos, concebidos e levados a efeito pelos habitantes locais, e não pelas agências e pelos profissionais do Direito e Desenvolvimento. As atividades de desenvolvimento jurídico seriam impulsionadas pela dinâmica local, interagindo com a dinâmica externa (incluindo atores externos econômicos e políticos). A assistência de estrangeiros com expertise jurídica poderia ser solicitada, mas os habitantes locais teriam de propor as iniciativas e controlar o processo completamente (como ocorre no desenvolvimento jurídico nos Estados Unidos). As prioridades e os recursos locais determinariam o que precisa ser feito.

Alguns dos projetos que atualmente acontecem por meio do Direito e Desenvolvimento provavelmente seriam propostos da mesma forma. Muito do mesmo conjunto de ideias reformistas circula em toda sociedade atualmente (ideias essas promovidas por ativistas, elites, atores econômicos, advogados comprometidos com a reforma jurídica etc.). Ordenamentos jurídicos corruptos ou em mau funcionamento são lamentados universalmente. As empresas e as comunidades locais necessitam de 
maneiras confiáveis e oportunas para resolver seus litígios. Os direitos dos trabalhadores e das mulheres são questões enredadas em todas as sociedades.

Mas também é provável que emergisse um conjunto diferente de projetos de desenvolvimento jurídico no lugar dos projetos hoje promovidos por meio do Direito e Desenvolvimento, e os projetos tomariam, quase que certamente, uma forma distinta. Sem desfrutar de um impulso artificial do dinheiro e da pressão vinda do exterior, os projetos de desenvolvimento jurídico necessitariam mobilizar apoio local suficiente de atores influentes para prevalecerem, em disputas regionais de caráter social/político, sobre a reforma. As prioridades e as pautas locais seriam adotadas. Os projetos seriam concebidos, conduzidos e executados por pessoas as quais entendem a situação, sabem o que é possível, compreendem quais compromissos devem ser feitos e possuem relacionamentos de longa data (capital social e político), dos quais podem lançar mão no decurso da execução. Nada disso assegura o sucesso das iniciativas de desenvolvimento jurídico - dado que ele é irregular e hesitante em todos os países -, mas esse processo consumadamente local de reforma jurídica se esquiva de muitas das principais falhas que atormentam os projetos de Direito e Desenvolvimento.

Uma implicação dessa tentativa de pensamento é que o longo registro de falhas dos projetos de Direito e Desenvolvimento nas últimas cinco décadas não implica necessariamente a constatação de que o desenvolvimento jurídico está fracassando. Em vez disso, significa que as metas do Direito e Desenvolvimento - na maioria das vezes relacionadas aos valores democráticos liberais e ao capitalismo - e os projetos não estão logrando muito êxito. No entanto, apesar dos malogros do Direito e Desenvolvimento, o desenvolvimento jurídico ainda acontece.

A China, por exemplo, é regularmente citada na literatura sobre Direito e Desenvolvimento como um fracasso, por não estabelecer tribunais independentes, pela corrupção, pelo assédio dos advogados ativistas e pelo controle partidário contínuo sobre o Poder Judiciário; ${ }^{59}$ contudo, nos últimos 25 anos, muitas leis novas foram aprovadas, o número de casos tratados pelo sistema judicial chinês aumentou dez vezes, um código nacional está sendo preparado, o mestrado em direito é praticamente obrigatório para uma posição judicial sênior, o número de advogados em atividade profissional independente passou de zero (anteriormente todos os advogados eram funcionários do Estado) para 118 mil advogados licenciados em 12 mil empresas, e, atualmente, são movidos mais de 150 mil processos judiciais anualmente contra o governo. ${ }^{60}$ Trata-se de um desenvolvimento jurídico substancial. E não é evidente que parte desse desenvolvimento possa ser atribuída aos projetos de Direito e Desenvolvimento.

Esse experimento mental ajuda a mostrar que os projetos de Direito e Desenvolvimento são intervenções externas em um ordenamento jurídico. Tal observação não é propriamente um motivo para condenação - muitas dessas iniciativas são 
bem intencionadas e poderiam até ser positivas, se funcionassem. Ela destaca apenas um fato crucial acerca das condições de seu funcionamento e de sua probabilidade de êxito. Intervenções externas em qualquer sociedade enfrentam barreiras as quais iniciativas internamente produzidas não encontram. O direito apresenta um desafio em especial para iniciativas externas, porque está profundamente imbricado num denso complexo de ordenamentos normativos internamente desenvolvidos, de bases de poder e incentivos que podem ser praticamente invisíveis ao lado externo. ${ }^{61}$

Por fim, essa tentativa de pensamento deixa claro que, enquanto os projetos de Direito e Desenvolvimento são uniformemente apresentados em benefício dos países beneficiários e seu povo, tais projetos não são, em geral, pelos ou dos países favorecidos e seu povo. As organizações e os profissionais do Direito e Desenvolvimento devem ser convocados para justificar os projetos de Direito e Desenvolvimento (metas, planos e modos de execução) perante os habitantes locais, bem como garantir sua aceitação genuína. Caso contrário, esses projetos podem incitar resistência a mais do mesmo antigo neoliberalismo imposto pelo Ocidente. No segundo plano da iniciativa de Direito e Desenvolvimento figura a ideia de que muitas dessas iniciativas jurídicas não são consensuais, mas impostas sob a forma de condições de "boa governança" que devem ser cumpridas pelos países beneficiários, a fim de garantir os empréstimos de instituições internacionais de financiamento. ${ }^{62}$ Historicamente, a pauta econômica e política dos doadores e seus agentes - não o altruísmo puro - tem estabelecido quais países estão aptos a obter o auxílio e quais programas serão realizados. 63

\section{INDO ADIANTE}

O “desenvolvimento jurídico" - que constrói e mantém instituições jurídicas do Estado - ocorre de maneira contínua em todas as sociedades. Contudo, ele tende a ser mais complexo e desafiador em contextos de desenvolvimento, por três razões em especial. Muitas dessas sociedades precisam enredar-se nos conflitos e nas tensões criadas pela proliferação existente de ordens concorrenciais e sobrepostas de cunho cultural, étnico, religioso e jurídico. ${ }^{64}$ Além disso, em muitas dessas sociedades, partes significantes do direito têm sido transplantadas de outros lugares, especialmente em relação ao direito comercial, sendo, portanto, pouco familiares à vida social e ao entendimento da população, ou distantes destes. ${ }^{65}$ Por fim, seus sistemas jurídicos são, com frequência, fracamente institucionalizados e possuem poder limitado; eles carecem de instituições jurídicas firmemente estabelecidas e as áreas fora das cidades comumente encerram uma presença jurídica pouco eficaz.

Apesar do teor altamente negativo do presente ensaio, produto do foco dado aos fracassos dos esforços empreendidos pelo Direito e Desenvolvimento, é preciso enfatizar que a mensagem deste texto não é rejeitar o desenvolvimento jurídico. 
Cada sociedade, hoje, requer um ordenamento jurídico eficaz que possa, no mínimo, gerenciar e apoiar as atividades dos sistemas modernos econômicos e de governo. Além disso, o grande benefício do Império do direito reside no estabelecimento de restrições legais ao governo, e apenas um sistema jurídico efetivo pode fornecer esse tipo de restrição. ${ }^{66}$ Por essas razões, o direito deve se aprimorar, e todos os esforços devem ser feitos a fim de auxiliar as instituições jurídicas a se desenvolverem de forma positiva, com a consciência de que este é um projeto infindável. Esforços contínuos de muitos habitantes locais são necessários para construir e manter um ordenamento jurídico em bom funcionamento. Um enorme obstáculo que impede tal esforço se refere ao fato de que, em diversos países, o governo (incluindo funcionários do alto escalão, legisladores e membros do judiciário) constitui uma parte importante do problema, já que tomado pela corrupção e por interesses enraizados que se beneficiam do status quo, embora projetos de reforma do Direito e Desenvolvimento sejam geralmente examinados pelos próprios funcionários públicos e precisem assegurar a aprovação destes, os quais se submetem a perder caso as reformas se mostrem eficazes. 67

É essencial no Direito e Desenvolvimento ser claro a respeito da meta ou das metas principais à mão. Vamos supor, por exemplo, que a meta seja aumentar a riqueza social global através da produção de mercadorias para exportação nos mercados globais. Consultar o conhecimento histórico, teórico e estatístico acerca do direito e capitalismo pode conduzir ao erro. Mesmo se for verdade que os direitos de propriedade estão historicamente associados ao crescimento do capitalismo e que, como os estudos mostram, há uma correlação positiva entre os direitos de propriedade e o desenvolvimento econômico, não se pode deduzir necessariamente que a melhor estratégia a curto prazo para promover o objetivo de desenvolvimento econômico num determinado país seja estabelecer o sistema jurídico. Se o sistema jurídico do Estado é apreendido numa reunião de forças - uma armadilha estrutural ou corrupção institucionalizada - que inexoravelmente enfraquece os esforços de reforma jurídica, então a melhor estratégia seria driblar tal sistema e encontrar ou criar outras organizações institucionais que facilitassem as atividades econômicas. Essa opção é, às vezes, criticada por desistir do ordenamento jurídico, assegurando seu subdesenvolvimento, mas considerar alternativas não significa negligenciar a legislação do Estado. Pode-se até mesmo constatar que, à medida que o desempenho econômico de um país aumenta, o sistema jurídico também se aprimora gradualmente - talvez por conta do aumento no conjunto de pessoas instruídas, da expansão da classe média e de sua demanda por melhores serviços jurídicos essenciais, da disponibilidade de financiamento adequado a fim de apoiar as instituições jurídicas, ou ainda porque os incentivos econômicos recompensam (e, portanto, encorajam) um sistema jurídico mais confiável e eficiente. Nada disso, naturalmente, é garantido, pois o que acontece é sempre um produto da combinação 
de fatores adjacentes, mas esse nexo de causalidade inverso (ou simultâneo) é tão plausível como as atuais alegações de que, melhorando o direito, o desempenho econômico também ira se aprimorar.

Uma discrepância angustiante, anteriormente mencionada, assombra a atual ênfase dada ao império de direito para o desenvolvimento econômico. Os países em desenvolvimento querem e precisam de desenvolvimento econômico agora. Isso é o que se espera que o Império do direito ajude a proporcionar. Existe um consenso geral, contudo, de que o estabelecimento do Império do direito é um projeto a longo prazo que ninguém sabe muito bem como realizar. Não obstante, a experiência recente confirma que pode ocorrer um progresso econômico explosivo sem a presença do Império do direito. Por exemplo, análises sugerem que as economias emergentes do BRIC (Brasil, Rússia, Índia e China), as quais têm sido citadas devido aos diversos fracassos dos esforços de desenvolvimento jurídico, estão, no entanto, estabilizadas para juntas competir e talvez superar, até a metade do século, as economias ocidentais avançadas (KRAMER, 2009).

Embora haja numerosos exemplos de progresso econômico sendo aprimorados por meio de políticas deliberadas, é difícil identificar quaisquer exemplos evidentes do Império do direito prevalecendo numa sociedade pela implementação de políticas deliberadas. O Império do direito baseia-se, em última análise, em atitudes culturais largamente partilhadas que apoiam o direito, as quais são difíceis de inculcar quando ausentes (e mais difícil ainda quando o direito ou os juízes são vistos com desconfiança). À luz disso, é incerto embarcar na construção do Império do direito como um meio indireto de facilitar o desenvolvimento econômico, quando poderiam muito bem haver formas mais convenientes de promover diretamente as metas mencionadas. Novamente, isso não significa enfaticamente que o desenvolvimento jurídico deva ser interrompido. Mas insiste na ideia de que o desenvolvimento jurídico e o econômico, ao interagirem de várias maneiras integrais, são projetos separados, cada qual se baseando em seu próprio mérito.

Agora, suponhamos que as metas (além de produzirem um crescimento econômico estável) visem a estabelecer uma política democrática, proteger os direitos civis, criar condições seguras de trabalho, propiciar uma distribuição justa e equitativa da riqueza, participar de um desenvolvimento ecologicamente sustentável, bem como conferir poderes às mulheres. Há poucos motivos para se pensar que qualquer uma dessas metas serão necessariamente promovidas por projetos de reforma judiciária ou pelo fortalecimento do Império do direito. O direito numa determinada sociedade, pode ignorar qualquer uma ou todas as metas; nem se deve supor que os juízes serão complacentes em relação ao avanço delas. A fim de que tal pacote progressista se torne realidade, profundas transformações sociais, políticas e culturais devem ocorrer em muitos países. O direito pode desempenhar uma função na promoção de tais mudanças, mas a combinação de forças sociais, culturais, econômicas 
e políticas será determinante. Acima de tudo, o que mais interessa na consecução desses objetivos é a advocacia. Eles podem ser promovidos de forma melhor se os ativistas trabalharem diretamente em nome de cada objetivo, em vez de depositarem suas esperanças no poder mágico do Império do direito (oportunistas que encobrem sua pauta pelo manto do Império do direito já atuam neste reconhecimento).

Por fim, suponhamos que a meta seja fornecer à população foros eficazes de resolução de controvérsias. Comumente, este é considerado o papel essencial dos tribunais do Estado. No entanto, é preciso ter em mente que, mesmo no Ocidente, o processo de arbitragem privada lida com uma parte substancial dos litígios. Em muitos contextos de desenvolvimento, os tribunais e o direito são fortemente problemáticos, por todas as razões descritas anteriormente. Faria sentido, portanto, investir recursos diretamente em alternativas existentes ou criar novos tribunais comunitários onde não há nenhum. Mais de $80 \%$ das pessoas nos países em desenvolvimento já levam seus litígios a tribunais não estatais; assim, apoiar tais alternativas será apenas uma questão de alinhamento à realidade. Em resposta a essas ações, as instituições jurídicas do Estado, confrontadas com um rival em potencial pelos recursos e pelo prestígio, poderiam ainda ser impelidas a melhorar seu funcionamento; ou esses diferentes sistemas poderiam, ao longo do tempo, fundir-se ou interagir de forma complementar.

A tendência de muitos, em especial os advogados, em supor que a legislação e os tribunais do Estado são a solução para os problemas enfrentados por esses países é produto de convicções ideológicas referentes ao monopólio do Estado sobre o direito. Em situações nas quais o ordenamento jurídico do Estado malogra em oferecer serviços básicos, quando as tentativas de reforma do sistema fracassam persistentemente, a solução precisa ser encontrada em outros lugares. Assim como alternativas funcionais ao direito podem satisfazer as necessidades do desenvolvimento econômico, tais alternativas podem igualmente servir a necessidades sociais, como a resolução de litígios, a manutenção da ordem e a coordenação de conduta. Os costumes e o direito consuetudinário, as normas e os grupos religiosos, e a comunidade ou as normas e os tribunais informais fazem grande parte deste trabalho em muitos lugares pelo mundo. O lugar de destaque que o direito reivindica ciosamente não deve ser um obstáculo na busca por soluções pragmáticas para problemas sociais, mesmo que isso signifique caminhar em torno de instituições jurídicas existentes.

A tendência mais recente do trabalho desenvolvido pelo Direito e Desenvolvimento já voltou suas atenções à exploração de alternativas sociais ao direito. ${ }^{68}$ É preciso dizer que tal fato também não é uma panaceia. Algumas dessas alternativas serão corruptas ou opressivas, ou serão controladas pelos detentores do poder local, ou irão impor punições draconianas, ou irão, ainda, reforçar as desigualdades culturais ou religiosas (sistemas de castas, difamação das mulheres). Esses sistemas alternativos serão especialmente problemáticos quando normas habituais e religiosas, ou pessoas agindo em seu próprio nome, são responsáveis por causar danos ou maus-tratos, ou quando a aldeia ou 
as instituições manifestam abusos de poder. ${ }^{69}$ Com essas amplas ressalvas, alternativas não estatais que funcionem de forma a satisfazer as necessidades e os valores da comunidade podem prestar um serviço essencial às pessoas que atualmente se veem abandonadas pelos sistemas jurídicos do Estado.

Essas observações finais trarão novamente à tona por que o "Direito e Desenvolvimento" é enganoso: o próprio rótulo sugere que o direito ou o "Império do direito" possui uma capacidade especial de atingir as metas de desenvolvimento almejadas. Com certeza tal convicção trará decepções. O direito não pode, porque ele nada no mar social junto com todo o restante. O desenvolvimento jurídico não está diretamente relacionado com o desenvolvimento do Império do direito (embora este possa resultar daquele). Ninguém sabe o que é o "Império do direito" em sentido concreto, assim como ninguém sabe como chegar a ele. O desenvolvimento jurídico envolve problemas específicos, que incluem o estabelecimento e o funcionamento do direto e das instituições jurídicas, bem como esforços concretos voltados à reforma. O desenvolvimento jurídico é uma iniciativa de varejo - refere-se à melhoria do funcionamento das instituições jurídicas, fazendo que estas atendam às necessidades da população, do governo e da economia. Embora eu tenha dúvidas acerca da iniciativa do Direito e Desenvolvimento, sou otimista em relação ao desenvolvimento jurídico.

: ARTIGO APROVADO (31/05/2010) : RECEBIDO EM 19/11/2009

\section{NOTAS}

1 Keynote Address, Conference on the Rule of Law, Nagoya University, Japão, 13 jun. 2009.

2 Ver TRUBEK, David M.; GALANTER, Marc. Scholars in Self-Estrangement: Reflections on the Crisis of Law and Development Studies in the United States, em Wis. L. Rev. n. 4, p. 1062-102, 1974. Disponível em português em: TRUBEK, David M.; GALANTER, Marc. Acadêmicos auto-alienados: reflexões sobre a crise norte-americana da disciplina "direito e desenvolvimento" (com Marc Galanter). In: O novo direito e desenvolvimento: presente, passado e futuro. Textos selecionados de David M. Trubek. São Paulo: Saraiva, 2009.

3 Ver SANTOS, Alvaro, The World Bank's Uses of the "Rule of Law" Promise in Economic Development. In: TRUBEK, David. M.; SANTOS, Alvaro (eds.). The New Law and Economic Development (Nova York: Cambridge University Press 2006). O autor fixa exclusivamente a contribuição do Banco Mundial em $\$ 3.8$ bilhões.

4 Um catálogo dos malogros comuns e persistentes pode ser encontrado em GOLUB, Stephen. A House Without a Foundation. In: CAROTHERS, Thomas. Promoting the Rule of Law Abroad (Washington D. C.: Carnegie Endowment, 2006).

5 Anteriormente, instiguei paciência. Ver TAMANAHA, Brian Z. The Lessons of Law and Development Studies, 
Am. L. Int'l. L., v. 89, p. 470-84, 1995. Disponível em português em: TAMANAHA, Brian Z. As lições dos estudos sobre direito e desenvolvimento. Revista DIREITO GV. São Paulo: DIREITO GV, v. 5, n. 1, jan-jun 2009, pp. 187-216.

6 Um artigo que enfoca a incapacidade de reconhecer essa percepção encontra-se em ALKON, Cynthia, The Cookie Cutter Syndrome: Legal Reform Assistance Under Post-Communist Democratization Programs, J. Disp. Resolution, v. 327, 2002; ver, também, TROOPE, Stephen, Legal and Judicial Reform through Development Assistance: Some Lessons, McGill, v. 48, n. 357, p. 387-390, 2003.

7 Kennedy usa essa frase em relação à elaboração de políticas, mas ela também se aplica ao direito.

8 Um esboço do denso ambiente social em que o direito opera pode ser encontrado em TAMANAHA, Brian Z. A General Jurisprudence of Law and Society (Oxford: Oxford University Press, 2001), p. 213-21.

9 Ver FRIEDMAN, Lawrence, On Legal Development, Rutgers L. Rev. v. 24, n. 11, 1969.

10 Para obter uma visão geral da situação econômica da Rússia, veja EASTERLY, William, White Man's Burden: Why the West's Efforts to Aid the Rest Have Done so Much Ill and so Little Good (Nova York: Penguin Books, 2006, p. 61-75).

11 Ver CONSTABLE, Pamela, Taliban Style Justice Stirs Growing Anger, Washington Post, 10 mai. 2009, disponível em: <http://www.washingtonpost.com/wp-dyn/content/article/2009/05/09/AR2009050902518.html>.

12 Veja, por exemplo, JENSEN, Erik G.; HELLER, Thomas, Beyond Common Knowledge: Empirical Approaches to the Rule of Law (Stanford: Stanford UnivERSITY Press, 2003).

13 Veja, por exemplo, TAYLOR, Steven L., Democratization in Latin America, Latin American Research Rev., v. 37, p. 162-72, 2002. Há aí um consenso de que os judiciários são os pilares mais fracos das democracias latino-americanas.

14 Ver TAmAnAHA, Brian Z. On the Rule of Law: History, Politics, Theory (Cambridge: Cambridge University Press, 2004).

15 Ver FITZPATRICK, Daniel. Disputes and Pluralism in Indonesian Law. Yale J. Int'l L., v. 22, p. 171-204, 1997. Uma soberba descrição da corrupção judicial na Indonésia pode ser encontrada em POMPE, Sebastian, The Indonesia Supreme Court: A Study of Institutional Collapse (Ithaca: Cornell Southeast Asia Program Publications, 2005).

16 Ver DAKOLIAS, Maria, Methods for Monitoring and Evaluating the Rule of Law, 2005, disponível em: $<$ http://www.cilc.nl./Conference -publication-2005.pdf>.

17 Uma oferta estimada feita por uma unidade do Banco Mundial é de 90\%. Ver WORLD BANK SOCIAL DEVELOPMENT UNIT, Forging the Middle Ground: Engaging Non-State Justice in Indonesia, mai. 2008 (paper).

18 Paul Collier desenvolve vários tipos de "armadilhas" em The Bottom Billion: Why the Poorest Countries are Failing and What Can be Done about It (Oxford: Oxford University Press, 2007).

19 Ver CHANNELL, Wade, Lessons Not Learned About Legal Reform, em CAROTHERS, Thomas, Promoting the Rule of Law Abroad (Washington D.C.: Carnegie Endowment, 2006, p. 137-44).

20 Ver EFFROS, Robert C., The World Bank in a Changing World: The Role of Legal Construction, Int'l Lawyer, v. 35, p. $1341-6,2001$.

21 Para uma excelente descrição desse programa e suas consequências nocivas, ver BRIETZKE, Paul H., The Politics of Legal Reform, Wash. U. Global Stud. L. Rev., v. 3, n. 1, 2004.

22 Ver DAKOLIAS, Maria, Methods for Monitoring and Evaluating the Rule of Law, 2005, disponível em: $<$ http://www.cilc.nl./Conference -publication-2005.pdf>.

23 Ver TRUBEK, David, Toward a Social Theory of Law: An Essay on the Study of Law and Development, Yale L. J., v. 82, n. 1,1972 . 
24 Ver KAUFMANN, Daniel; KRAAY, Aart; Massimo Mastruzzi, Governance Matters VI: Aggregate and Individual Governance Indicators, p. 1996-2006, World Bank Policy Research Working Paper Series, n. 4280, jul. 2007; HAMILTON, Kirk et.al., Where is the Wealth of Nations? Measuring Capital for the $21^{\text {st }}$ Century (Washington: The World Bank, 2006).

25 Comunicado à Imprensa n. 2002/013/S, Rule of Law Central to Fighting Poverty, World Bank President Calls on Governments to Recognize the Link Between Law and Development, disponível em: <http://web.worldbank.org/ WBSITE/EXTERNAL/NEWS>.

26 Robert Danino, The Legal Aspects of the World Bank's Work on Human Rights, out. 2006, disponível em: <http://www1. worldbank.org/devoutreach/october06/article. asp?id=386>.

27 Ver CROSS, Frank B., Law and Economic Growth, Tex. L. Rev., v. 80, 2002.

28 Ver, por exemplo, AGRAST, Mark David et al., The World Justice Project Rule of Law Index: Measuring Adherence to the Rule of Law Around the World, American Bar Association, 2008. Para um estudo critico de tais medidas, ver THOMAS, Melissa A., What Do the Worldwide Governance Indicators Measure?, out. 2006, disponível em: <http://siteresources. worldbank.org/INTWIBGOVANTCOR/Resources/1740479-114912210081/2604389. 1167941884942 /what_do_wgi_measure.pdf>.

29 Um dos principais criadores de tais estudos, Daniel Kaufmann, do Banco Mundial, reconhece que questões sobre causalidades permanecem não resolvidas. Ver: KAUFMANN, Daniel. Rethinking Governance: Empirical Lessons Challenge Orthodoxy, 11 mar. 2003

30 Ver RODRIK, Dani, One Economics, Many Recipes: Globalization, Institutions, and Economic Growth (Princeton: Princeton University Press, 2007).

31 Idem.

32 Ver HAMILTON, Kirk et.al., Where is the Wealth of Nations? Measuring Capital for the $21^{\text {st }}$ Century (Washington: The World Bank, 2006.

33 Idem.

34 Ver ClARKE, Donald; MURRElL, Peter; Whiting, Susan, The Role of Law in China's Economic Development, disponível em: $<$ http://ssrn. com/abstract $=878672>$.

35 Ver GINSBURG, Tom, Does Law Matter for Economic Development? Evidence from East Asia, Law \& Soc'y Rev., v. 34, p. 829, 2000; UPHAM, Frank, Mythmaking in the Rule-of-Law Orthodoxy. In: CAROTHERS, Thomas. Promoting the Rule of Law Abroad (Washington D.C.: Carnegie Endowment, 2006).

36 Ver OHNESORGE, John K. M., Developing Development Theory: Law \& Development Orthodoxies and Northeast Asian Experience, U. Pa. J. Int'l Econ. L., v. 28, p. 219, 2007.

37 Idem.

38 Ver, em geral, FRIEDAN, Jeffry A., Global Capitalism: Its Fall and Rise in the Twentieth Century (Nova York: W. W. Norton, 2006).

39 Ver DIXIT, Avinash K., Lawlessness and Economics (Princeton: Princeton University Press, 2004).

40 Ver RODRIK, Dani, One Economics, Many Recipes: Globalization, Institutions, and Economic Growth (Princeton: Princeton University Press, 2007); DAVIS, Kevin E.; TREBILCOCK, Michael J., Legal Reforms and Development, ThirdWorld Q., v. 22, p. 21-7, 2001.

41 Ver DAKOLIAS, Maria, Methods for Monitoring and Evaluating the Rule of Law, 2005, disponível em: $<$ http://www.cilc.nl./Conference -publication-2005.pdf>. 
42 Muitos críticos se pronunciaram sobre as várias maneiras inconsistentes em que o "Império do direito" é utilizado no contexto de desenvolvimento. Ver HAGGARD, Stephan; MACINTYRE, Andrew; TIEDE, Lydia, The Rule of Law and Economic Development, Annual Rev. Pol. Sci., v. 11, 2008; Kleinfeld, Rachel, Competing Definitions of the Rule of Law. In: CAROTHERS, Thomas, Promoting the Rule of Law Abroad (Washington D.C.: Carnegie Endowment, 2006).

43 Uma articulação realista das interligações de apoio pode ser encontrada em O’DONNELL, Why the Rule of Law Matters, Journal of Democracy, v. 15, p. 32-46, 2004

44 Ver TAmanAHA, Brian Z., On the Rule of Law: History, Politics, Theory (Cambridge: Cambridge University Press, 2004), capítulos 3 e 8.

45 IRBD Articles of Agreement, artigo III, seção 4, VII. O nome oficial do Banco Mundial é Banco Internacional para Reconstrução e Desenvolvimento.

46 IRBD Articles of Agreement, artigo IV, seção 10.

47 Ver FRIEDAN, Jeffry A., Global Capitalism: Its Fall and Rise in the Twentieth Century (Nova York: W. W. Norton, 2006).

48 Essa explicação foi retirada de uma admirável descrição de EFFROS, Robert C., The World Bank in a Changing World: The Role of Legal Construction, Int'l Lawyer, v. 35, p. 1341-6, 2001.

49 Ver OHNESORGE, John K. M., On Rule of Law Rhetoric, Economic Development, and Northeast Asia, Wisc. Int'l. L. J., v. 25, 2007.

50 Meus dois anos de permanência em Yap corroboram isso. Ver TAMANAHA, Brian Z., Understanding Law in Micronesia: An Interpretive Approach to Transplanted Law (Leiden: Brill, 1993). Uma narrativa de advertência pode ilustrar a questão. Durante meu período por lá, dois consultores educacionais externos vieram a Yap para uma visita de duas semanas, entrevistaram diversos funcionários do governo (incluindo a mim, na qualidade de assessor jurídico do Departamento de Educação) e, posteriormente, redigiram um relatório descrevendo as propostas de reformas do sistema educacional. O relatório baseou-se num entendimento incorreto da verdadeira dinâmica da situação e, que eu saiba, fracassou (embora os consultores tenham ganhado uma generosa quantia pelos seus esforços).

51 Para uma ampla descrição dos esforços empregados pelos Estados Unidos, ver DE LISLE, Jacques, Lex Americana? United States Legal Assistance, American Legal Models, and Legal Change in the Post-Communist World and Beyond, U. Pa. J. Int'l. Econ. L., v. 20, p. 179, 1999.

52 Ver DAM, Kenneth, The Law-Growth Nexus: The Rule of Law and Economic Development (Washington: Brookings, 2006).

53 Ver FITZPATRICK, Daniel, Disputes and Pluralism in Indonesian Law, Yale J. Int'l L., v. 22, p. 171-204, 1997.

54 Para uma descrição dos danos causados às mulheres por conta da escrituração, ver MANJI, The Politics of Land Reform in Africa: From Communal Tenure to Free Markets (Londres: Zed Books, 2006).

55 Ver TAmanAHA, Brian Z., Understanding Legal Pluralism: Past to Present, Local to Global, Sydney L. Rev., v. 30, p. 375, 2008 .

56 Para um exemplo dessa incerteza, ver EASTERLY, William, White Man's Burden: Why the West's Efforts to Aid the Rest Have Done so Much Ill and so Little Good (Nova York: Penguin Books, 2006).

57 Ver TAMANAHA, Brian Z. Law as a Means to an End: Threat to the Rule of Law (Nova York: Cambridge University Press, 2006), capítulos 6 e 7.

58 Para um exemplo recente de tal ceticismo, ver TRUBEK, David M, The "Rule of Law" in Development Assistance: Past, Present, and Future, em TRUBEK, David. M.; SANTOS, Alvaro (eds.), The New Law and Economic Development (Nova York: Cambridge University Press 2006). 
59 Ver THORNTON, John, Long Time Coming: The Prospects for Democracy in China, Foreign Affairs, v. 87, n. 2, p. $10-3,2008$.

60 Idem, p. 10-1.

61 Uma visão geral a este respeito pode ser encontrada em TAMANAHA, Brian Z., A General Jurisprudence of Law and Society (Oxford: Oxford University Press, 2001). Um dos melhores estudos dos entraves que o Direito deve confrontar está presente em MOORE, Sally Falk, Law as Process (Boston: Routledge \& Kegan Paul, 1978).

62 Ver EASTERLY, William, White Man's Burden: Why the West's Efforts to Aid the Rest Have Done so Much Ill and so Little Good (Nova York: Penguin Books, 2006), p. 146.

63 Essa questão é vigorosamente demonstrada em EASTERLY, William, White Man's Burden: Why the West's Efforts to Aid the Rest Have Done so Much Ill and so Little Good (Nova York: Penguin Books, 2006).

64 Ver, em geral, , Brian Z., Understanding Legal Pluralism: Past to Present, Local to Global, Sydney L. Rev., v. 30, p. 375,2008

65 Ver: TAMANAHA, Brian Z. A General Jurisprudence of Law and Society (Oxford: Oxford University Press, 2001), capítulo 5 .

66 Ver: TAMANAHA, Brian Z. On the Rule of Law: History, Politics, Theory (Cambridge: Cambridge University Press, 2004), capítulo 11.

67 Ver: EASTERLY, William. White Man's Burden: Why the West's Efforts to Aid the Rest Have Done so Much Ill and so Little Good (Nova York: Penguin Books, 2006), capítulo 4.

68 Ver WORLD BANK SOCIAL DEVELOPMENT UNIT, Forging the Middle Ground: Engaging Non-State Justice in Indonesia, mai. 2008 (paper); FITZPATRICK, Daniel, Disputes and Pluralism in Indonesian Law, Yale J. Int'l L., v. 22, p. 171-204, 1997; DONOVAN, Dolores A.; ASSEFA, Getachew, Homicide in Ethiopia: Human Rights, Federalism, and Legal Pluralism, Am. J. Comp. L., v. 51, p. 505, 2003; RITTICH, Kerry, The Future of Law and Development: Second Generation Reforms and the Incorporation of the Social. In: TRUBEK, David. M.; SANTOS, Alvaro (eds.), The New Law and Economic Development (Nova York: Cambridge University Press 2006).

69 Ver DONOVAN, Dolores A.; ASSEFA, Getachew, Homicide in Ethiopia: Human Rights, Federalism, and Legal Pluralism, Am. J. Comp. L., v. 51, p. 505, 2003.

\section{REFERÊNCIAS BIBLIOGRÁFICAS}

CAROTHERS, Thomas. The Rule of Law Revival. Em CAROTHERS, Thomas. Promoting the Rule of Law Abroad. Washington D.C.: Carnegie Endowment, 2006. Rule of Law Temptations. The Fletcher Forum of World Affairs, v. 33, 2009.

CHANNELL, Wade. Lessons Not Learned about Legal Reform. In: CAROTHERS, Thomas. Promoting the Rule of Law Abroad. Washington D.C.: Carnegie Endowment, 2006.

COLLIER, Paul. The Bottom Billion: Why the Poorest Countries are Failing and What Can be Done about It. Oxford: Oxford University Press, 2007.

COMMISSION ON GROWTH AND DEVELOPMENT. The Growth Report: Strategies for Sustained Growth and Inclusive Development. Washington: The World Bank, 2008.

CROSS, Frank B. Law and Economic Growth. Tex. L. Rev., v. 80, 2002.

DAVIS, Kevin; TREBILCOCK, Michael J. Legal Reforms and Development. ThirdWorld Q., v. 22, p. 21-7, 2001. 895-7, 2008. The Relationship between Law and Development: Optimists Versus Skeptics. Am. J. Comp. L., v. 56, p.

DAM, Kenneth. The Law-Growth Nexus: The Rule of Law and Economic Development. Washington: Brookings, 2006. 
DODSON, Michael. Assessing Judicial Reform in Latin America. Latin Am. Research Rev., v. 37, p. 200-2, 2002. EASTERLY, William. White Man's Burden: Why the West's Efforts to Aid the Rest Have Done so Much Ill and so Little Good. Nova York: Penguin Books, 2006.

EFFROS, Robert C. The World Bank in a Changing World: The Role of Legal Construction. Int'l Lawyer, v. 35, p. 1341-6, 2001.

GARTH, Bryant G. Building Strong and Independent Judiciaries through the New Law and Development: Behind the Paradox of Consensus Programs and Perpetually Disappointing Results. DePaul L. Rev, v. 53, 2002.

GOLUB, Stephen. A House Without a Foundation. In: CAROTHERS, Thomas. Promoting the Rule of Law Abroad. Washington D.C.: Carnegie Endowment, 2006.

HAGGARD, Stephan; MACINTYRE, Andrew; TIEDE, Lydia. The Rule of Law and Economic Development. Annual Rev. Pol. Sci., v. 11, 2008.

KENNEDY, David. The "Rule of Law", Political Choices, and Development Common Sense. Em TRUBEK, David. M.; SANTOS, Alvaro (Eds.). The New Law and Economic Development. Nova York: Cambridge University Press 2006. KRAMER, Andrew E. Four Nations Seek More Diversity in Global Economic Order. New York Times, 17 jun. 2009 MANJI, Ambreena. The Politics of Land Reform in Africa: From Communal Tenure to Free Markets. Londres: Zed Books, 2006.

NORTH, Douglass C.. Institutions, Institutional Change and Economic Performance. Nova York: Cambridge University Press, 1990.

Economic Performance through Time. Am. Econ. Rev., v. 84, p. 359-66, 1994.

O’DONNELL, Guillermo. Why the Rule of Law Matters. Journal of Democracy, v. 15, p. 32-46, 2004.

PHILlIPS, Kevin, Bad Money: Reckless Finance, Failed Politics, and the Global Crisis of American Capitalism. Nova York: Penguin Books, 2009.

PIRON, Laure-Helene. Time to Learn, Time to Act in Africa. Em CAROTHERS, Thomas. Promoting the Rule of Law Abroad. Washington D.C.: Carnegie Endowment, 2006.

REINERT, Erik S.. How Rich Countries Got Rich and Why Poor Countries Stay Poor. Nova York: Public Affairs, 2007.

SANTOS, Alvaro. The World Bank's Uses of the "Rule of Law" Promise in Economic Development. In: TRUBEK, David. M.; SANTOS, Alvaro (Eds.). The New Law and Economic Development. Nova York: Cambridge University Press, 2006.

SEN, Amartya. What is the Role of Legal and Judicial Reform in The Development Process, World Bank Legal Conference, Wash. D.C., June 5, 2000.

SPENCE. The Complexity of Success in Russia. Em CAROTHERS, Thomas. Promoting the Rule of Law Abroad. Washington D.C.: Carnegie Endowment, 2006.

STEPHENSON, Matthew. A Trojan Horse in China. Em CAROTHERS, Thomas. Promoting the Rule of Law Abroad. Washington D.C.: Carnegie Endowment, 2006.

TROOPE, Stephen. Legal and Judicial Reform through Development Assistance: Some Lessons. McGill, v. 48, p. 387-393, 2003.

TRUBEK, David M. The "Rule of Law" in Development Assistance: Past, Present, and Future. Em TRUBEK, David. M.; SANTOS, Alvaro (Eds.). The New Law and Economic Development. Nova York: Cambridge University Press, 2006.

WILLIAMSON, Oliver E. The New Institutional Economics: Taking Stock, Looking Ahead. J. of Econ. Literature, v. 38,2000 .

Brian Z. Tamanaha 